\title{
Antimony Deposits
}

of El Antimonio District Sonora, Mexico

GEOLOGICAL SURVEY BULLETIN 962 -B

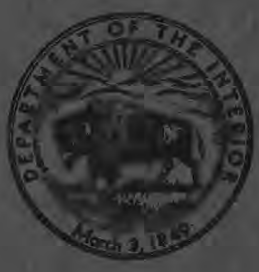




\section{Antimony Deposits}

of El Antimonio District

Sonora, Mexico

$B y$ DONALD E. WHITE and REINALDO GUIZA

GE OL OGICAL S U R VEY B U L LET IN 962-B

Prepared in cooperation with the

Universidad Nacional Autonoma de México, Instituto de Geologia, and the Comite Directivo Para la Investigacion de los Recursos Minerales de México under the auspices of the

Interdepartmental Committee on Scientific and Cultural Cooperation, Department of State

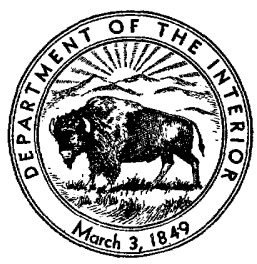




\section{UNITED STATES DEPARTMENT OF THE INTERIOR}

J. A. Krug, Secretary

GEOLOGICAL SURVEY

W. E. Wrather, Director 


\section{CONTENTS}

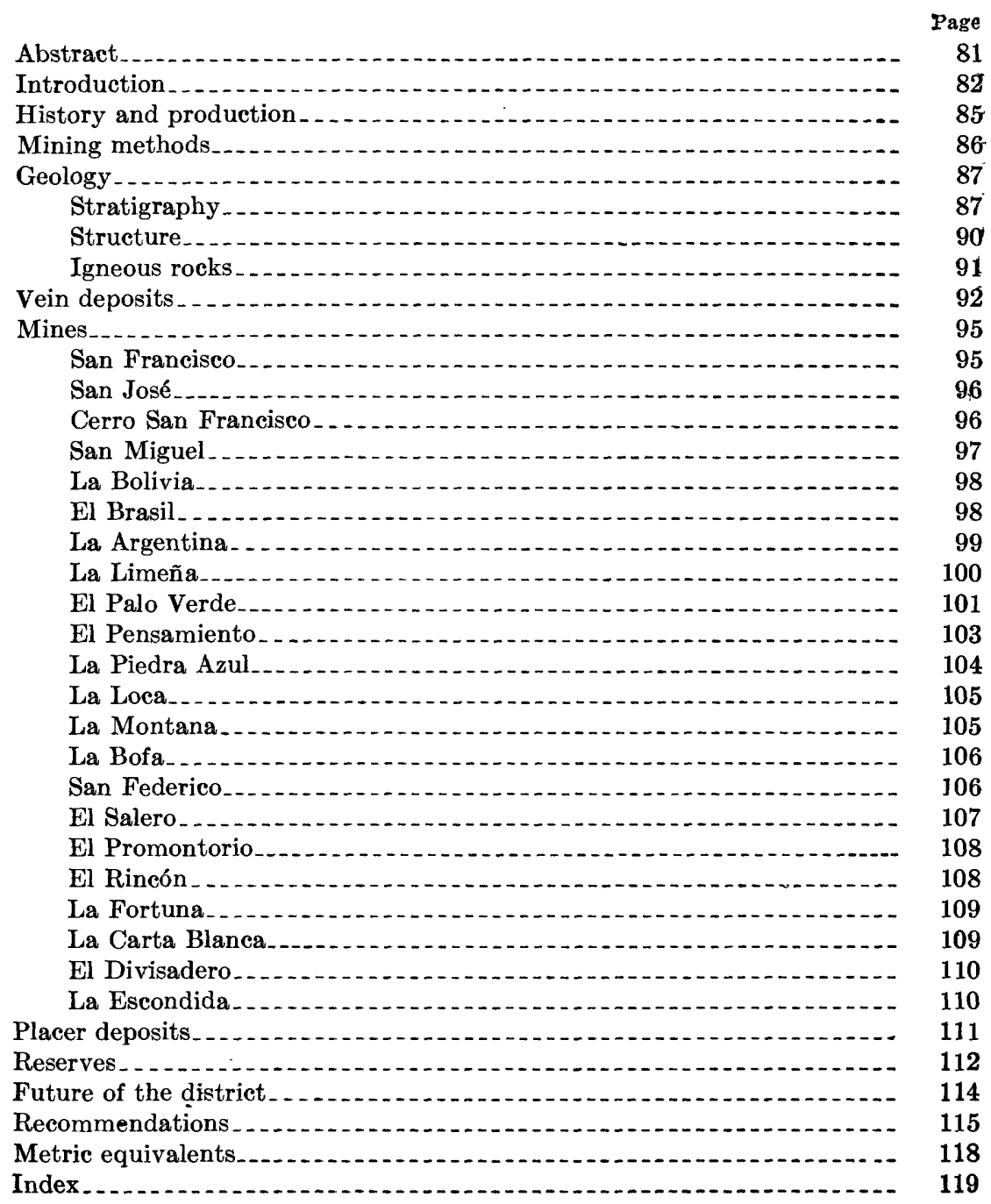




\section{ILLUSTRATIONS}

Plate 13. Geology of the Cerro San Francisco area............. in pocket

14. Geology of the San Francisco area................. in pocket

15. Geology of the La Montana area .................. in pocket

16. Surface and underground geology of the east vein of La Argentina mine.......... in pocket

17. Geology and section of La Limeña mine.............. in pocket

18. Geology and section of the north veins of El Palo Verde mine. . . . . . . . . . .

19. Geology of El Pensamiento mine ................... in pocket

20. Geology of La Piedra Azul mine.................. in pocket

21. Geology of La Montana mine........ in pocket

22. Geology of EI Salero mine............ in pocket

23. Geology of the south vein of El Promontorio mine........ in pocket

24. Geology of the La Fortuna area............. in pocket

25. Geology of the La Escondida area......... in pocket

Figdre 4. Map of the northwestern part of Mexico............. 82

5. Map of the El Antimonio district............ 


\title{
ANTIMONY DEPOSITS OF EL ANTIMONIO DISTRICT SONORA, MEXICO
}

\author{
By Donald E. White and Reinaldo Guiza
}

\section{ABSTRACT}

The El Antimonio district is in the northwestern part of the Estado de Sonora, Mexico, about 160 kilometers by road west of Santa Ana, the nearest shipping point, and 100 kilometers south of Ajo, Arizona.

Its estimated past production is about 20,000 or 25,000 tons of metallic antimony. This amount has been exceeded by only one or two other antimony districts in Mexico.

The bedrocks of El Antimonio district consist largely of sandstone, siltstone and conglomerate of Triassic and Lower Jurassic age unconformably overlying limestone of Permian age. These rocks are intruded by dikes and irregular bodies of quartz porphyry, diorite, and trachyte. The Triassic rocks are cut by thrust faults of small displacement, more or less parallel to the stratification, and by small cross faults. The thrust faults and in places the cross faults are occupied by veins containing quartz, oxides of antimony, and locally gold, chloride and bromide of silver, and chalcedony. Postmineral faults are common, but all of them are of small displacement.

Two formations consisting of indurated gravel occur in the district. One is distinctly older than the other, but both are of Recent age. They have been mapped separately. The present stream channels contain unconsolidated gravels which are younger than the indurated gravels; these have not been mapped. All the gravel deposits contain antimony minerals, and all except the oldest have been worked as placers.

The district contains 22 mines working the largest and the richest of the veins, which are mostly in the Triassic siltstone but partly in the Triassic sandstone and intrusive igneous rocks. In addition, a hundred or more smaller veins are known. The ore is generally localized in the flatter-dipping parts of the veins and at or below the intersections of the main veins with premineral faults and fractures.

The mines contain no ore that is "measured" in the sense of having been proved and sampled, for the reason that the ore bodies are always mined out as soon as they are discovered. The term "indicated" reserves, is applied to ore contained in those parts of the veins and placers that have been explored to some extent; such reserves have not been measured or carefully sampled, but are estimated to be 46,000 to 73,000 metric tons of ore containing 2,950 to 8,850 metric tons of antimony. The "inferred" reserves consist of ore that operators may reasonably expect to find in the unexplored parts of the known veins and in undiscovered placers and veins to a depth of 150 meters below the surface. Inferred reserves are estimated to be 76,000 to 203,000 metric tons of ore containing 14,200 to 38,850 tons of antimony. The grand total of all reserves is estimated to be 122,000 to 276,000 tons of ore containing 17,150 to 47,700 tons of antimony. 


\section{INTRODUCTION}

The El Antimonio district is in the northwestern part of the Estado de Sonora, Mexico (fig. 4), near $112^{\circ} 33^{\prime}$ west longitude and $30^{\circ} 44^{\prime}$

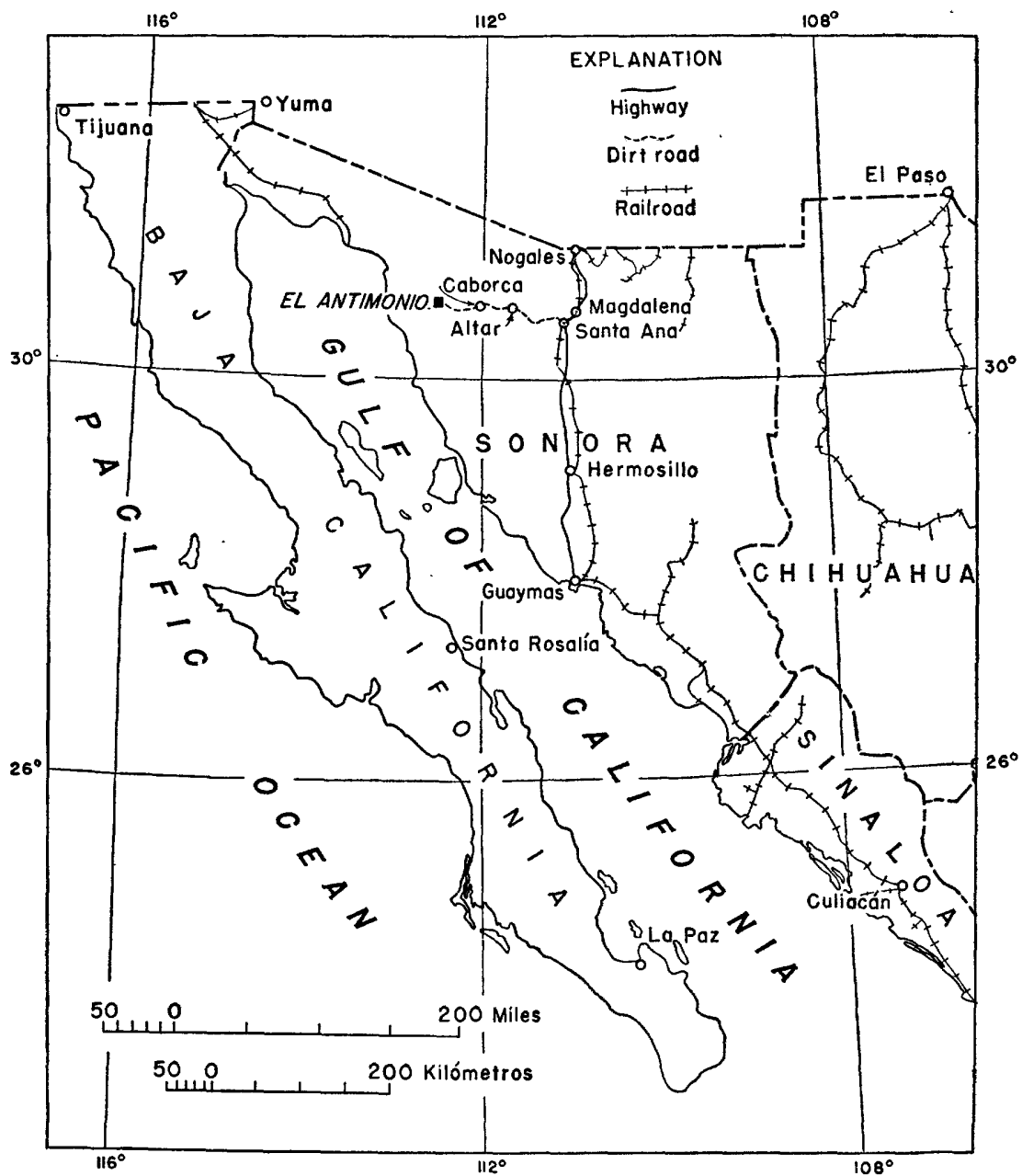

Figure 4.-Map of the northwestern part of Mexico, showing the location of the EI Antimonio district.

north latitude. It lies about 100 kilometers nearly due south of Ajo, Ariz., and is 160 kilometers by dirt road west of Santa Ana, the nearest shipping point, on the Southern Pacific Railroad of Mexico. Because of the dry climate prevailing in northwestern Sonora, the road, though not in very good condition, is passable during most of the year. Santa Ana is 119 kilometers by improved dirt road south of the border town of Nogales, Ariz. 
Topographically, the district consists of a northward sloping and north-eastward sloping pediment, or bedrock surface, underlain by nonresistant sedimentary rocks and mantled with a thin cover of alluvium. Hills consisting of limestone of Permian age and massive igneous rocks of Tertiary age rise as much as 200 meters above the pediment slope, which ranges in altitude from 150 meters at the north end of the district to 275 meters at the south end. The climate is dry, its annual rainfall never being more than a few inches. In spite of the aridity of the region, the water table is only 10 to 55 meters below the surface of the pediment, probably because of the low altitude of the district and its proximity ot the Gulf of California, which is only 40 kilometers to the west.

The principal mines are owned by Roberto Moreno, of Santa Ana, Sonora, and of Mexico, D. F. Three of the smaller deposits in the district, the La Fortuna, La Carta Blanca, and El Divisadero mines, are owned by Rafael Ruiz of El Antimonio, who also holds a lease on the La Loca mine, owned by Roberto Perez of Caborca, Sonora.

The authors, Donald E. White of the United States Geological Survey and Ing. Reinaldo Guiza, Jr., of the Instituto de Geologia de México, spent 6 weeks, from May 4 to June 15, 1943, in the field. Five separate mineralized areas, containing 22 mines, were mapped on a scale of 1:2,500 and with a contour interval of 5 meters. As none of the underground workings had been surveyed previously, all of them were carefully mapped in detail by tape and compass. Underground maps of only the eight most important mines are included in the present report; the workings of the other mines are small or consist of irregular "gopherings." Although antimony deposits are distributed through an area $7 \frac{1}{2}$ kilometers long from north to south and 1 to 3 kilometers wide, only the 5 or 6 square kilometers containing the main centers of mineralization were mapped in detail. (See fig. 5.)

The writers take pleasure in acknowledging the hospitality and cooperation given by Roberto Moreno and his associates, especially Eduardo Richardson, Roberto Moreno, Jr., and Manuel Lemas. Rafael Ruiz was very helpful in relating the history of the district.

This is one of a series of detailed studies of the antimony deposits of Mexico, which were investigated by the United States Geological Survey and the Instituto de Geologia de México. The investigation was part of a cooperative program sponsored by the Interdepartmental Committee for Scientific and Cultural Cooperation, under the auspices of the Department of State. 


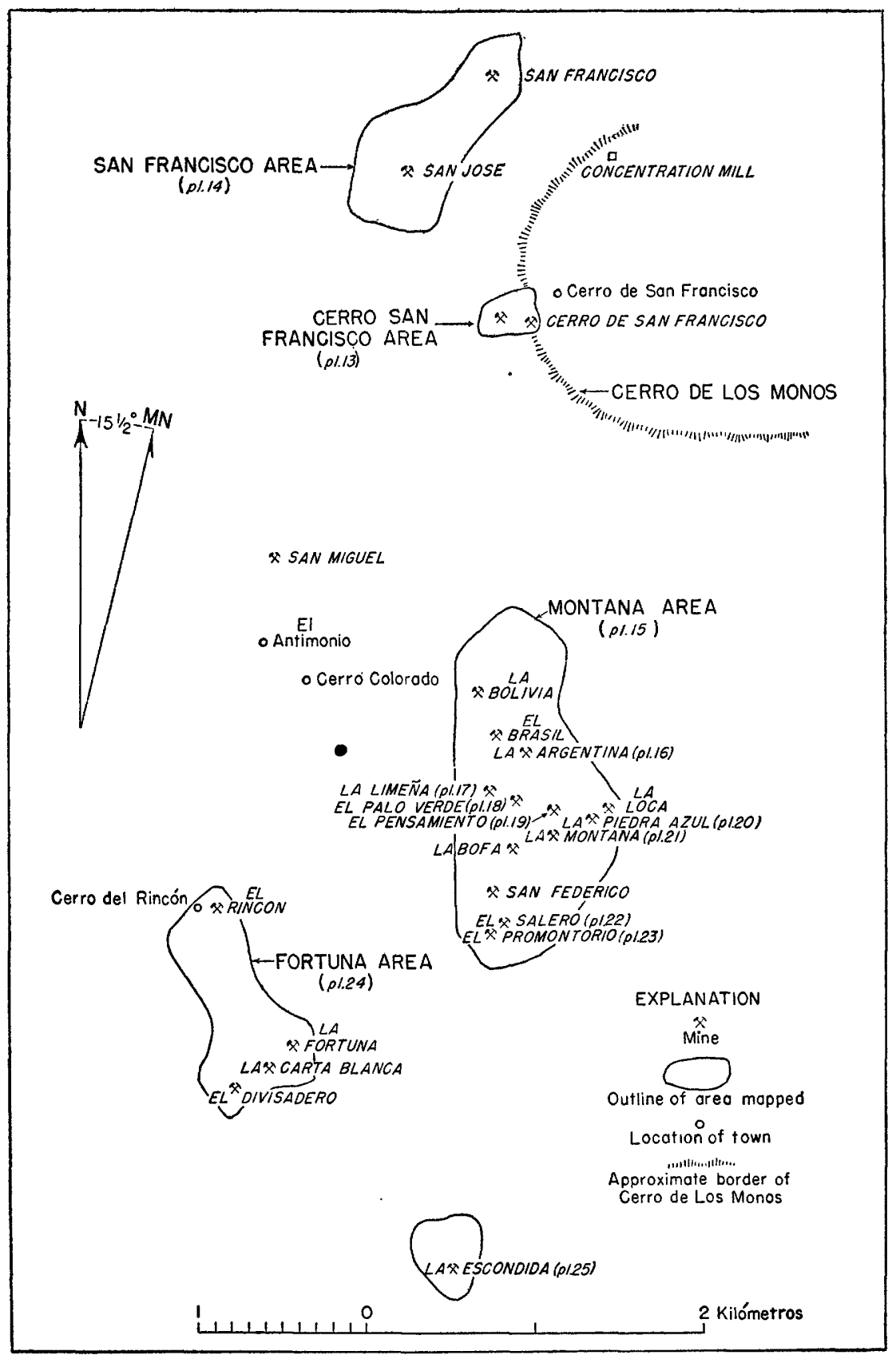

FIGURE 5.-Map of the El Antimonio district, showing the mines and areas mapped in detail. 


\section{HISTORY AND PRODUCTION}

The history of the deposits is far from complete. According to Rafael Ruiz of El Antimonio, it was known as early as 1722 that the area contained mineral deposits. About 1882 a company controlled by Boston interests owned an area 8 to 10 kilometers long and 1 kilometer wide in the central part of the district. Antimony and some high-grade silver ore, occurring in three vein systems, were produced principally from the San José mine and in lesser quantity from the La Argentina mine. Two of the vein systems were named after these two mines; a third was called the Santa Margarita, but that name is no longer used in the district. The maximum depth of the workings at that time is said to have been 10 meters. Figure 5 shows the location of the principal mines.

Rafael Ruiz came to the district in 1912, and since then has been connected with the development of a large number of the deposits. For many years Ruiz sold his ore to Charlie Thompson, an American, but in 1924 Roberto Moreno became the ore-buying agent in Santa Ana, and in the following year Moreno and Thompson became partners in buying ore and mines as well as in taking up new claims. Some years later Thompson died, leaving Moreno as the principal operator. New deposits were discovered at intervals of 1 to 2 years. The discovery of important ore bodies in La Piedra Azul mine was made in 1942 and in 1943, although the first vein had been discovered in this mine about 1936.

No detailed records were kept of the production from individual mines. In the early days the largest producers were La Argentina, San Miguel, and San José mines. From 1924 to about 1930 they were the La Argentina, La Montana, El Promontorio, and San Francisco mines, and in recent years they have been the La Montana, El Palo Verde, La Limeña, El Pensamiento, San Francisco, and La Fortuna mines. Since 1942 the La Piedra Azul mine has been the most productive.

Because of the general absence of records the total past production from the district is not known, but it is estimated to be about 20,000 or 25,000 metric tons of metallic antimony. At least 10 percent of it came from placer deposits. This total has been exceeded in Mexico only by the Wadley district, in San Luis Potosí, and possibly by the Soyatal district, in Querétaro. In 1942 the production from the El Antimonio district was about 950 metric tons of metal, which was exceeded by the Tejocotes district in Oaxaca and by the Wadley and Soyatal districts.

Shipments from the Moreno properties consist partly of high-grade, hand-sorted ore containing about 45 percent of antimony, and partly 
of mill concentrates containing about 50 percent of antimony. During the first five months of 1943 the average total monthly production of high-grade ore was 98 metric tons. Of this amount about 62 tons was produced from the La Piedra Azul, La Limeña, and El Palo Verde mines by miners working for a standard wage per day. The remaining 36 tons was produced by gambusinos, or independent miners, who are free to work wherever they wish, not only in the Moreno mines but in most of the other mines and in the placer deposits. All of them sell their ore to Moreno. Slightly more than half of this ore is produced from veins and the rest from the placer workings.

Moreno has been experimenting for several years with mill concentration of low-grade ore. His first attempt, in which he used a stamp mill, proved unsuccessful after a short trial. In October 1942 he started a Chilean mill, but this was shut down and dismantled late in January 1943. He then built a new mill, employing a combination of mechanical jigs and tables, which went into operation late in March 1943. During May and June this mill was still in an experimental stage, but it was already producing better results than those previously employed and was proving to be a profitable investment. The mill has a rated capacity of 100 metric tons of ore per 24-hour day, but it is usually run at less than half its capacity. From ore containing 13 to 15 percent of antimony, about 50 percent of the antimony is said to be recovered in a 50 -percent concentrate. When ore containing more than 15 or less than 13 percent of antimony is milled, the recovery is said to decrease. All the antimony is in the form of oxides, for which no efficient low-cost methods of concentration have yet been developed. The average monthly production in the future will probably be from 60 to 80 metric tons of concentrates.

The monthly production from the mines owned or operated by Rafael Ruiz is somewhat erratic, but in the future it will probably be about 15 metric tons of ore containing 45 percent of antimony.

\section{MINING METHODS}

Most of the old workings in the district consist of irregular "gopherings" made by gambusinos, who follow stringers and bodies of ore without regard to systematic development of the deposits. Mining practice here is different in some respects from that encountered in any other antimony district in Mexico. Some of the veins crop out at the surface, but many that are partly or completely covered with alluvium are found by tracing concentrations of placer ore in the stream beds. When a vein is discovered, it is mined down the dip to a depth of less than 10 meters, then developed to a greater depth by sinking vertical shafts in the hanging wall to intersect the vein. 
The vein is usually mined upward, and in rare instances downward, from each place where it is intersected by a shaft. Some veins have been developed from six or eight different shafts, and many shafts are no more than 7 to 10 meters apart. All mining is done by hand methods, and, except at the four principal mines in the district, the ore and waste are removed from the vertical shafts by means of hand hoists. There are two reasons for the very extensive inefficient use of these vertieal shafts: (1) No mechanical equipment, such as rails and ore cars, is used underground, all rock material being carried on men's backs except in the larger mines, where wheelbarrows are used on the main levels; and rather than carry ore for long distances by hand; the miners expend a great deal of effort in sinking closely spaced shafts. (2) Many of the veins are partly or entirely covered with alluvium, which in places is as much as 4 meters thick. Shafts extending into or through the alluvium are used in prospecting areas where the presence of a vein is suspected, or where placer deposits are known to exist.

During recent years some of the mines have been systematically developed by means of levels and a few crosscuts Gasoline horsts are used in the main shaft of each of the three principal producing mines, the La Piedra Azul, La Limeña, and El Palo Verde, and roists were used in the past at the now inactive La Montana and El Pensamiento mines. Gasoline engines of 6 to 8 horsepower are used at the three producing mines to hoist buckets having a capacity of 0.3 cubic meter. In the mines extending below the water level, the buckets are also used to remove the water. Ore cars and rails are used only on the surface, at the three largest mines. The entire district probably does not contain more than some 250 meters of double track and 8 or 10 ore cars.

\section{GEOLOGY}

\section{STRATIGRAPHY}

The rocks of El Antimonio district consist for the most part of a great thickness of Triassic and Jurassic sedimentary strata, which unconformably overlie limestone of Permian age and are intruded by dikes and irregular bodies of quartz porphyry, fine-grained diorite, and trachyte. Recent gravels are the youngest rocks in the area.

East of the Cerro San Francisco mine, the Cerro de los Monos, of middle Permian ${ }^{1}$ limestone (see fig. 5), rise hundreds of feet higher than the Triassic rocks, wh:ch are generally in fault contact with the limestone. In places, however, the Triassic rocks overlie the Permian with slight to marked unconformity. In the Cerro San Francisco mine area (pl. 13), the contact between Permian rocks (unit A) and

1 Cooper, G. A., oral communication. 
Triassic rocks (unit B) is regarded as unconformable and is displaced by a number of faults. About 1 kilometer to the southeast, the basal Triassic rocks have, for a distance of several hundred meters, an average strike of $\mathrm{N} .22^{\circ} \mathrm{W}$. and a dip of $63^{\circ} \mathrm{W}$. In the same interval the adjacent Permian rocks also dip $63^{\circ} \mathrm{W}$. but have an average strike of N. $29^{\circ} \mathrm{W}$.

The Triassic rocks are chiefly red calcareous sandstone and siltstone but include some interbedded calcareous sandstone, limestone, and conglomerate. They are mostly unfossiliferous, but in several places they contain abundant poorly preserved fossils; in a few places they yielded many good fossils. The upper beds in the sequence contain fossils that are regarded as Lower Jurassic in age.

Gravel deposits of three ages are found in the district; the two older deposits are cemented and the youngest is uncemented. The older of the two cemented gravels, mapped as older alluvium, is found for the most part in the higher, southern half of the area, where it overlies a somewhat irregular bedrock surface. This gravel deposit attains a thickness in some places of 25 meters or more.

General stratigraphic sequence in El Antimonio district

\begin{tabular}{|c|c|c|c|}
\hline Age & Formation & Character & $\begin{array}{l}\text { Thickness } \\
\text { (meters) }\end{array}$ \\
\hline \multirow{3}{*}{ Quaternary. } & $\begin{array}{l}\text { Uncemented grav- } \\
\text { els. (Not map- } \\
\text { ped). }\end{array}$ & $\begin{array}{l}\text { Youngest gravels, generally not oemented, lying in } \\
\text { present gullies. }\end{array}$ & $0-2$ \\
\hline & Younger alluvium. & $\begin{array}{l}\text { Cemented gravels overlying a bedrock surface nearly } \\
\text { parallel to the present topography. These gravels } \\
\text { contain most of the placer deposits. }\end{array}$ & $0-312$ \\
\hline & \multirow{2}{*}{$\begin{array}{l}\text { Older alluvium } \\
\text { - Unconformity }\end{array}$} & $\begin{array}{l}\text { Cemented gravels, generally in the southern part of the } \\
\text { area, lying on an irregular bedrock surface. }\end{array}$ & $0-25$ \\
\hline Jurassic. & & $\begin{array}{l}\text { Fine-grained and coarse-grained gray and tan sandstone } \\
\text { with a few beds of gray-green shale. The top of the } \\
\text { unit was not seen. Some ammonites found in shale } \\
\text { well above the base of the unit indicate age to be } \\
\text { Lower Jurassic. }\end{array}$ & $200 \pm$ \\
\hline \multirow[b]{2}{*}{ Triassic. (?) } & Unit $\mathbf{H}$. & $\begin{array}{l}\text { Rocks grading upward from shale through sandstone } \\
\text { to conglomerate. The pebbles in the conglomerate } \\
\text { are as much as } 15 \text { centimeters in diameter and consist } \\
\text { of quartzite and quartz porphyry. }\end{array}$ & $200 \pm$ \\
\hline & Unit $\mathbf{G}$. & $\begin{array}{l}\text { Gray limestone, interbedded with gray sandstone and, } \\
\text { in places, with gray and red shale. The limestone } \\
\text { and shale contain poorly preserved fossils. This unit } \\
\text { is relatively resistant to erosion and is the best horizon } \\
\text { marker in the area. }\end{array}$ & $25 \pm$ \\
\hline
\end{tabular}


General stratigraphic sequences in El Antimonio district-Continued.

\begin{tabular}{|c|c|c|c|}
\hline Age & Formation & Character & $\begin{array}{l}\text { Thickness } \\
\text { (meters) }\end{array}$ \\
\hline \multirow{5}{*}{ 'Trinssir. } & Unit F. & $\begin{array}{l}\text { Brown sandstone, interbedded with red and gray silt- } \\
\text { stone and a few beds of limestone, in the upper part } \\
\text { of the unit; dark-gray sandstone in the middle part, } \\
\text { lower part largely greenish sandstone, weathering } \\
\text { to dark brown. Some poorly preserved fossils of } \\
\text { Upper Triassic (Karnic or Noric) age were found in } \\
\text { the middle and upper parts. Some of the rocks, es- } \\
\text { pecially the siltstone in the upper part, contain } \\
\text { antimony veins. }\end{array}$ & $250 \pm$ \\
\hline & Unit E. & $\begin{array}{l}\text { Gray, red-weathering siltstone, mostly with little or no } \\
\text { stratification. There are few outerops. The silt- } \\
\text { stone is sandy in some places and calcareous in others. } \\
\text { At the Cerro Colorado (see fig. 5) equivalent rocks } \\
\text { are well-bedded, with thin beds of limestone contain- } \\
\text { ing a large fauna of Upper Triassic (Karnic) ammo- } \\
\text { nites described by Burckhart } 3 \text { and verified by } \\
\text { Reeside. }{ }^{4} \text { This unit contains many of the large } \\
\text { antimony veins of the district. }\end{array}$ & $200 \pm$ \\
\hline & Unit $\mathrm{D}$. & $\begin{array}{l}\text { Largely reddish-purple and gray sandstone with a few } \\
\text { beds of limestone and conglomerate. Red and gray } \\
\text { unstratified siltstone is rather abundant in the upper } \\
\text { part. The top of the unit is a massive bed of dark- } \\
\text { gray sandstone and the bottom is a } 15 \text {-meter bed of } \\
\text { conglomerate containing limestone lenses with a } \\
\text { few ammonites. Some antimony veins occur in the } \\
\text { formation, particularly in the siltstone of the upper } \\
\text { part. }\end{array}$ & $300 \pm$ \\
\hline & Unit C. & $\begin{array}{l}\text { Upper part mainly red and yellow-brown shale with } \\
\text { a few beds of limestone, generally with reddish bor- } \\
\text { ders. Interbedded gray sandstone is rather abun- } \\
\text { dant near the top. Lower part mainly red and red- } \\
\text { brown medium-grained sandstone interbedded with } \\
\text { coarse sandstone and fine conglomerate. The forma- } \\
\text { tion contains some poorly preserved fossils. }\end{array}$ & $500 \pm$ \\
\hline & -Unconformity & $\begin{array}{l}\text { Predominantly massive red calcareous sandstone, with } \\
10 \text { meters or more of conglomerate near the middle of } \\
\text { the unit. The boulders in the conglomerate are as } \\
\text { much as } 30 \text { centimeters in diameter; some consist of } \\
\text { limestone containing fossils that appear to be similar } \\
\text { to those found in the upper part of the underlying } \\
\text { Permian rocks. Other beds of conglomerate occur } \\
\text { near the base of the unit, but the basal beds consist } \\
\text { mainly of red calcareous sandstone or siltstone. } \\
\text { arently with a very slight angular discordance in places) }\end{array}$ & $250 \pm$ \\
\hline Permian. & Unit A. & $\begin{array}{l}\text { Limestone and sandy limestone, with red and gray } \\
\text { sandstone near the middle of the unit. The age of } \\
\text { of the rocks, according to Cooper, }{ }^{s} \text { is middle Permian. }\end{array}$ & $500 \pm$ \\
\hline
\end{tabular}

- Reeside, J. B., written communication.

Burckhart, C. E., Etude Synthetique sur le mesozoique Mexican: Mem. Soc. Paleont. Suisse, vol. 49, 1929.

4 Reeside, J. B., written communication.

S Cooper, G. A., oral communication. 
The younger of the two cemented gravels, mapped as younger alluvium, covers much of the central and northern parts of the district. The deposit is commonly 1 meter to $3 \frac{1}{2}$ meters thick, mantling a pediment or bedrock surface that is nearly parallel to the present topographic surface. It contains most of the placer material of the area.

The youngest gravels, which have not been mapped, lie in the present gullies and are generally not cemented. Their maximum thickness is probably not more than 1 or 2 meters.

The general stratigraphic sequence in the El Antimonio district was determined by reconnaissance methods except for the parts of the section that crop out within the areas mapped in detail. It may be summarized as shown in the above table.

\section{STRUCTURE}

Triassic rocks surround the Cerro de los Monos on the north, west, and south, and in general they dip away from the hills which are made up of Permian rocks. (See fig. 5.) The Triassic rocks in the San Francisco-San José mine area, northwest of the Cerro de los Monos, strike northeast and dip almost vertically. (See pl. 14). Those rocks in the Cerro San Francisco mine area (pl. 13), west of the contact with the Permian, strike about N. $15^{\circ} \mathrm{W}$. and dip west. The rocks south of the hills (pl. 15) generally strike northwest and dip to the southwest.

The Triassic rocks are cut by several systems of faults, generally of small displacement. The most prominent system, containing many of the antimony veins, consists of thrust faults that are more or less parallel to the bedding. The dips of the faults range from horizontal to $90^{\circ}$, and the strikes vary throughout the district. Mineralized thrust faults dipping toward the Cerro de los Monos and across the bedding of the Triassic rocks are found only in the Cerro San Francisco area (pl. 13). At some places in the district there are many premineral cross faults, probably in part contemporaneous with the thrust faults and in part later. The faults in the system that contains the greatest number strike from N. $25^{\circ} \mathrm{W}$. to N. $30^{\circ} \mathrm{E}$. and usually dip to the east. Those in another system strike from N. $60^{\circ}$. E. to due east, and generally dip southeast. In some of the mines postmineral faults of small displacement are abundant. These faults generally strike N. $20^{\circ}$ W.,to N. $30^{\circ}$ E. In many places postmineral movement within and parallel to the main veins has occurred on the premineral cross faults. Slickensides are found on oxidized antimony ore in the La Piedra Azul mine; the oxidized antimony ore of the El Salero mine has been brecciated by faulting that is later than the 
oxidation. The faults in the mine areas do not affect the present topography. Airplane photographs of the region, however, show a recent fault in the alluvial gravels about 15 miles southeast of the area shown in figure 3. This fault, distinguishable for a distance of several miles, strikes northwest toward the Montana group of mines.

The thrust fault in the Cerro de San Francisco area (pl. 13) strikes nearly due north and dips about $40^{\circ} \mathrm{E}$. Its total displacement is estimated to be 20 to 100 meters. After the major movement dikes of fine-grained diorite and of trachyte were intruded along and across the fault plane. After a second period of thrust movement, antimony ore was deposited in the fault.

\section{IGNEOUS ROCKS}

The igneous rocks in the district consist of three general types: (1) White quartz porphyry forms dikes, sills, and irregular masses. Large bodies 500 meters or more in diameter underlie the Cerro Divisadero, the Cerro Promontorio, and a number of unmapped hills between and south of the two "cerros." (2) Dark fine-grained diorite forms dikes and irregular masses as much as several hundred meters in diameter. The largest bodies of diorite underlie the Cerro del Rincón, the Cerro la Limeña, and the area between the La Bofa mine and the San Frederico mine. (3) Purple-brown trachyte occurs chiefly in dikes, which are found only in the northern part of the La Montana area and in or near the Permian limestone of the Cerro de los Monos.

The relative ages of the igneous rocks are not definitely known. On the Cerro Promontorio (pl. 15) small bodies of diorite apparently cut the quartz porphyry, and in the Cerro San Francisco mine the trachyte apparently cuts diorite. The probable order of intrusion was therefore porphyry, diorite, trachyte. The general age of these rocks are also unknown except that they are post-Triassic and probably post-Jurassic. They are tentatively considered to be Tertiary (?) in age. 


\section{VEIN DEPOSITS}

The antimony ore is found for the most part in veins of various strikes and dips in an area $7 \frac{1}{2}$ kilometers long from north to south and 1 to 3 kilometers wide. Figure 5 shows the distribution of the mineraljzed centers that have been mapped in detail and also the location of the individual mines in each area. Most of the large veins are found in red or gray siltstone, commonly calcareous, in Triassic units D, E, and $\mathrm{F}$, in which the stratification is generally obscure. El Brasil, La Argentina, La Limeña, El Palo Verde, El Pensamiento, La Piedra Azul, La Montana, El Salero, and El Promontorio mines are entirely or largely in siltstone. The San Francisco, San José, La Bolivia, La Bofa, San Federico, and La Escondida mines are entirely or largely in reddish-gray and gray sandstone, which is the second most abundant wall rock. The veins of the EI Rincón mine and many of the minor veins near the San Federico mine are in fine-grained diorite. La Fortuna, La Carta Blanca, and EI Divisadero mines are in quartz porphyry. La Loca mine is partly in quartz porphyry and partly in siltstone, and the Cerro San Francisco and San Miguel mines are both in trachyte and sandstone.

The antimony veins apparently avoid limestone, even where it is abundant, as in the San José mine and near the El Salero and El Promontorio mines: The Permian rocks, which consist predominantly of limestone, are not known to contain any antimony deposits. This situation is in contrast to that in the other large antimony districts in Mexico; in all of these the antimony ore is almost restricted to limestone.

Most of the veins in the sedimentary rocks are parallel or nearly parallel to the stratification. In general the veins and the stratification bear a somewhat symmetrical relation to the Cerro de los Monos of Permian limestone. In the San Francisco area (pl. 14) the rocks and the veins strike northeast and dip to the northwest or are overturned to the southeast. In the northern part of the Montana area (pl. 15) the beds and veins strike about $N^{\top} .30^{\circ} \mathrm{W}$. and dip at moderate angles to the southwest, but farther to the south they strike west and southwest. In the El Promontorio mine, at the south end of the area, they strike S. $30^{\circ}$ to $65^{\circ} \mathrm{W}$. and lie flat or dip southeast at angles that reach $45^{\circ}$.

Most of the fissures occupied by veins are on thrust faults of small displacement, in which the hanging walls have usually moved not only upward but also westward relative to the footwalls. Premineral cross faults, generally striking to the north and northeast and dipping steeply to the east or west, cut the main faults, the west sides of which are thrown relatively southward. The vertical component of move- 
ment on these premineral cross faults is not known. Later mineralization was largely restricted to the thrust faults; the cross faults are generally barren.

Hundreds of antimony-bearing veins have been found in the district. Most of them are of little or no economic importance, but thirty or more have been mined to a considerable extent. Most of the veins consist predominantly of coarse-grained milky-white quartz, but in one mine, the Piedra Azul, the gangue consists mainly of fine-grained chalcedony. The veins in the producing mines average about 30 centimeters in width and 100 meters in length, with a maximum width of 3 meters and a maximum length of 500 meters. The ore deposits are very thoroughly oxidized.

The writers saw only a few grains of the primary antimony sulfide, stibnite, in the area, and they saw none in the deepest mines, La Limeña and EI Palo Verde. The La Limeña has been mined to a. depth of 60 meters, which is about 3 meters below the water table in that locality. Appreciable quantities of stibnite have been found only in the San Francisco mine, where the surface is lower than at any other mine in the district and the water table is only 10 meters below the surface. The vein was mined to a depth of 35 to 40 meters; 3 or 4 tons of sulfide ore is said to have been extracted from the lower workings.

At a somewhat greater depth the oxides will probably be succeeded abruptly by sulfides. Such a change is also to be expected in La Limeña and El Palo Verde mines at a depth of 20 to 50 meters below the present workings. The depth to the water table is not known for any of the other mines in the district, but in most, the ground-water level is probably about 20 to 40 meters below the present workings.

The antimony oxides exhibit a wide variety of color. They are mostly straw yellow and yellow brown, but in part nearly milk white, brown, or bluish gray. Greenish-black and black oxides, which have not been observed by the author in any other antimony deposits, are also fairly abundant, forming stain on quartz and shells around other oxides. These minerals were not identified specifically because the mineralogy of the antimony oxides in general has not been satisfactorily worked out. The nature of most of them cannot be readily determined by the usual methods, because all have high indices of refraction, and the X-ray patterns of several of the commonest are very similar.

The El Salero, La Argentina, and La Montana veins contain appreciable amounts of silver, as a bromide or mixed bromide and chloride, coating the walls on fractures. This mineral is bright yellow green when fresh, but rapidly changes to greenish black upon exposure to sunlight.

$840118-49-2$ 
Native gold is found in some of the veins, principally the EI Pensamiento, El Palo Verde, and La Limeña. The gold occurs mainly in coarse-grained quartz near antimony ore, but there is a unique type of ore in which the walls of fractures cutting nearly pure antimony oxide are coated with secondary gold. The fractures were developed after the oxidation of the primary stibnite.

The antimony ore forms irregular high-grade bodies in quartz and chalcedony veins, concentrations on the walls of the veins, and lowgrade disseminations throughout the veins. The ore is generally most abundant in the flatter dipping parts; in places where the strike of a vein changes; and at and below the structural dams that are formed at intersections of steep premineral cross faults with the main flatly dipping veins. The most effective dam is formed by a cross fault that is nearly parallel in strike to the vein; ore is scarce or absent where the strike of a premineral cross fault is nearly perpendicular to that of the vein.

Because of the absence of records, exact figures on the size and grade of individual ore bodies cannot be given. In most antimony mines, however, the average grade of a deposit is less important than the relative abundance of ore than can be sorted to a product of shipping grade, containing 40 percent or more of antimony. The vein material in the large ore body north of the main shaft in the La Piedra Azul mine contains, on the average, about 20 percent of antimony, but most of the ore bodies probably contain only 5 to 15 percent. Up to June 15, 1943, the large La Piedra Azul ore body had yielded about 400 tons of ore, and probably at least as much remained to be mined. Judging from the size of the old stopes in the La Argentina, La Montana, La Limeña, El Pensamiento, San Francisco, and La Fortuna mines, some of the largest ore bodies probably contained as much as 1,000 tons of shipping ore, but the average content, if we take all the mines into account, probably does not exceed 50 metric tons of shipping ore. Few of the ore bodies are more than 50 meters long, 15 meters deep, or $2 \frac{1}{2}$ meters wide.

The relative importance of the various structural controls differs greatly in different mines. Flattening of dip has had a marked influence in the La Piedra Azul, La Limeña, El Promontorio, and La Carta Blanca mines and is influential to a lesser degree in La Argentina and El Pensamiento mines; where the dips are flat, the veins generally widen and become richer. Changes of strike are probably less important ore controls in these mines. Intersections of veins and fractures have proved highly favorable in La Montana, La Bofa, El Salero, La Argentina, San Miguel, and La Fortuna mines, and favorable to a lesser extent in the La Piedra Azul, San José, and San Francisco mines. 
In such mines as El Pensamiento, El Palo Verde, San Federico, El Brasil, La Bolivia, Cerro de San Francisco, El Rincón, El Divisadero and La Escondida, changes in strike and dip and structural intersections are absent or weakly developed, and the general absence of these features is believed to account for the lack of large ore concentrations in these mines. The El Pensamiento and the El Palo Verde mines contain considerable amounts of antimony ore, mostly on the walls of the veins; this ore is distributed more or less uniformly throughout the mines, with few marked concentrations. The richer portions of the veins are believed to be localized by small variations in dip and strike, and if the variations had been larger the ore would probably have been concentrated to a much greater degree.

All the known veins in the district are found within a few hundred meters of igneous intrusions. Many of them are in the igneous rocks; some occupy fractures that are believed to have formed as a result of the cooling of the intrusions. The relations of the veins to the quartz porphyry and to the diorite seem equally close. Trachyte intrusions are rare but are found in two of the mines. The veins are not directly related to the near-surface intrusions but are believed to be genetically related to a common source below the surface.

\section{MINES}

The mines are described in geographical order from north to south.

\section{SAN FRANCISCO}

The San Francisco mine (pl. 14) is in red-gray sandstone that may be the equivalent of the Triassic (?) unit G. The vein is parallel to the beds or cuts them at low angles. The deposit contains either two veins or, more probably, a single vein with an offset of 12 meters near its central part. The mine was one of the most productive in the district from about 1925 to 1935 but it was inactive in 1943. Only the near-surface workings are accessible, because the water level is only 10 meters below the surface. The main shaft, which is in the center of an arroyo, is said to be about 35 meters deep; there are three levels, at depths of 13 meters, 25 meters, and 31 meters. The vein is entirely concealed by alluvium except in a few places west of the arroyo, where it consists of 30 centimeters of brecciated and altered wall rock with about 10 centimeters of low-grade antimony ore on the hanging wall. The vein has a known length of 200 meters. It strikes N. $45^{\circ}$ to $70^{\circ} \mathrm{E}$.; at the surface it dips $85^{\circ} \mathrm{N}$. on the west side of the arroyo and $75^{\circ}$ to $85^{\circ} \mathrm{S}$. on the east side. Near the surface, ore was mined only east of and under the arroyo, but in the middle and lower levels, where the vein is said to flatten to the north, rich ore as much 
as 3 meters wide was mined along a large part of the vein. Ore was reported below the lower level, but the flow of water was so large that the vein could not be mined to greater depths. The lowest workings, however, are closer to sea level and farther below the water table than those in any of the other mines in the district. This is also the only mine in the district that yielded an appreciable amount of stibnite. Although the ore is largely oxidized to the greatest depths attained, about 4 tons of sulfide ore was mined from below the second level.

No igneous intrusions crop out near the mine, but the area is largely covered with alluvium. Several beds of sedimentary rock near the west end of the vein may be volcanic in origin, but they are much older than the veins and are not genetically related to them.

The mine probably warrants reopening and exploration below the present levels. Not far below the present workings the ore may consist predominantly of stibnite.

\section{SAN JOSÉ}

The veins of the San José mine (pl. 14) are in red micaceous sandstone. They have an average length of 75 meters; their average strike is $\mathrm{N} .35^{\circ} \mathrm{E}$., approximately parallel to that of the sedimentary rocks, and they dip steeply to the northwest and southeast, generally cutting. the beds at low angles. The sandstone beds containing the veins are separated by beds of fossiliferous blue-gray limestone, which according to the paleontological evidence ${ }^{6}$ may be the equivalent of the Triassic (?) unit G. Quartz porphyry crops out north and west of the mine. The maximum depth of the workings is 18 meters, but as the old workings are filled the greatest accessible depth is now 9 meters. The depth to the water table is not known but is probably 5 to 10 meters below the deepest workings. Although some of the ore is found in simple veins, the best is found on intersections of steeply dipping veins that diverge laterally and downward. Where the walls. are less than 2 to 5 meters apart, high-grade ore fills the space between the two walls; where the distance is greater, ore is found only on the walls. The mine has never been a large producer; in May and June 1943, a few gambusinos mining on a small scale were recovering less. than 1 ton of ore per week.

The mine probably contains undiscovered ore, but no specific recommendations can be given as to its development.

\section{CERRO SAN FRANCISCO}

The Cerro San Francisco mine (pl. 13) consists of two veins about. 200 meters apart, neither of which was being worked in June 1943. The western vein, 70 meters long, is in red calcareous sandstone and

- Reeside, J. B., oral communication. 
fine-grained diorite. It strikes N. $35^{\circ}$ E. and dips $40^{\circ}$ to $60^{\circ} \mathrm{E}$.; the bedding in the sandstone strikes about N. $10^{\circ} \mathrm{W}$. and dips $55^{\circ}$ to $75^{\circ} \mathrm{W}$. The vein, which has yielded only a few tons of ore, is 10 centimeters to 1 meter wide and has been mined to a depth of 8 meters.

The eastern vein occupies the fissure of a late thrust fault, which cuts a trachyte dike injected along an earlier thrust fault of fairly large displacement. The faults strike from due north to N. $10^{\circ} \mathrm{E}$. and $\operatorname{dip} 35^{\circ}$ to $50^{\circ} \mathrm{E}$. The upper beds of the Permian limestone have been thrust upon the basal formation of the Triassic rocks, which consist of red calcareous sandstone of Triassic unit B. The vein fills a brecciated zone up to 1 meter wide, with stringers of quarts and antimony oxide. It is about 100 meters long and has been worked down the dip for a maximum distance of 15 meters. The best ore was found in the more flatly dipping parts of the vein, but none of the ore bodies is large or of high grade, and the total production has been small. The mineralized part of the fault is restricted to the trachyte and does not extend north or south into the fine-grained diorite or into those parts of the early thrust fault that do not contain intrusive rocks.

The chances of discovering large new ore bodies in this property do not appear to be good.

\section{SAN MIGUEL}

The ore deposits in the San Miguel mine (fig. 5) are in a vein striking N. $40^{\circ}$ to $50^{\circ} \mathrm{E}$. and dipping $28^{\circ}$ to $58^{\circ} \mathrm{SE}$. The fissure occupied by the vein is cut by three small, closely spaced, premineral reverse faults that strike $\mathrm{N} .55^{\circ} \mathrm{E}$. and dip $75^{\circ}$ to $85^{\circ} \mathrm{SE}$. The maximum thickness of the vein is 3 meters and its average thickness is about 50 centimeters. Most of the ore in this vein has been concentrated in and below intersections with the steep faults, and the largest ore body that has been found is in the more flatly dipping part of the vein. The vein and the faults are terminated on the west by a fault that strikes N. $20^{\circ} \mathrm{E}$. and dips steeply to the east. This fault may be postmineral, although no surface continuation of the vein has been found west of the fault. The wall rock consists chiefly of purple arkosic sandstone, possibly of Triassic unit D, striking N. $15^{\circ} \mathrm{E}$. and dipping $55^{\circ} \mathrm{E}$., but includes a little highly altered trachyte.

The mine contains no regular levels. The vein has been mined in what is essentially one large stope, 30 meters long and 15 meters in vertical depth. Two shafts, now inaccessible, were sunk to intersect the vein at a greater depth, but apparently little or no ore was found. In June 1943 two gambusinos were mining the deposit and were producing about 1 ton of ore per week. The mine has produced only a few hundred tons of ore, and its rate of production is unlikely to 
increase. There may be an offset segment of the vein west of the fault. striking N. $20^{\circ} \mathrm{E}$., but this possibility is not supported by the exposures. on the surface.

\section{LA BOLIVIA}

The La Bolivia mine (pl. 15) contains three rather widely separated veins in the gray sandstone of Triassic unit $D$. On the average, the veins are about 20 centimeters wide and less than 50 meters long. The north vein strikes about N. $70^{\circ} \mathrm{W}$. and dips $50^{\circ} \mathrm{S}$.; the other two strike N. $20^{\circ}$ to $30^{\circ} \mathrm{W}$. and dip $50^{\circ}$ to $75^{\circ} \mathrm{W}$., nearly parallel to the bedding. None of the workings on the veins are more than about 10 meters deep except one 15-meter shaft, which was sunk to intersect the middle vein at a greater depth, but from which little or no ore was produced.

In June 1943 four gambusinos were working on the north and south veins, but the middle vein was not being mined. A little ore was being recovered, particularly from the more flatly dipping parts of the veins, but the variations in dip are so small that there has been little concentration of ore. Total past production is probably not greater than 100 to 200 metric tons of shipping ore. The mine does not seem especially promising, but it may contain undiscovered ore at depth.

\section{EL BRASIL}

The El Brasil mine (pl. 15) contains two parallel veins, about 10 meters apart, striking about N. $55^{\circ} \mathrm{W}$. and dipping $38^{\circ}$ to $50^{\circ} \mathrm{SW}$. Both veins are parallel to the bedding of red and gray siltstone, and they are separated by the massive bed of gray sandstone that constitutes the uppermost part of Triassic unit $D$. One of the veins is 40 meters long and the other 140 meters. The longer, which has yielded most of the ore, is cut near its northwest end by a third vein, which is in a premineral fault fissure striking from due north to $\mathrm{N}$. $20^{\circ} \mathrm{E}$. and dipping $25^{\circ}$ to $60^{\circ} \mathrm{E}$. The fault has been mineralized for a distance of 60 meters. A large part of the longest vein has been mined to a depth of more than 15 meters down the dip, but the lower workings are filled with waste. The deepest vertical shaft intersecting the vein is over 20 meters deep and is said to have yielded a considerable amount of ore. The average width of the veins where they have been stoped is probably at least 30 centimeters and the average width of the unmined portion is about 10 centimeters. Most of the ore has come from the parts of the veins that dip less than $45^{\circ}$, although some of the ore waslocalized at the intersection of the two cross-cutting veins.

The past production is probably between 500 and 1,000 metric tons of ore. The mine probably contains undiscovered ore at depth, 
for there the dips may flatten and the main vein must intersect the cross-cutting northeast vein. The water table is probably at least 20 meters below the present workings.

\section{LA ARGENTINA}

The La Argentina mine (pl. 15) contains at least 6 veins, all but one of which strike N. $45^{\circ}$ to $60^{\circ} \mathrm{W}$. and dip $40^{\circ}$ to $70^{\circ} \mathrm{SW}$., nearly parallel to the stratification of the enclosing purple-gray sandstone and siltstone of Triassic units $\mathrm{D}$ and $\mathrm{E}$.

According to local reports, the eastern vein (pl. 16), which is 280 meters long and 10 centimeters to 2 meters wide, has been the most productive in the mine and possibly in the entire district. Although no records are available, the total past production from this one vein is probably between 2,000 and 4,000 metric tons of shipping ore.

The deepest accessible workings in the vein are 29 meters below the surface The mine contains about 200 meters of accessible workings but has no regular levels Near the southeast end of the vein is an inaccessible vertical shaft that is said to be nearly 40 meters deep, but the shaft and the workings are filled to a depth of 15 meters. A 17-meter shaft cutting the middle part of the vein revealed a small amount of ore, but the workings from this shaft are not extensive. This part of the vein is 10 to 20 centimeters wide and contains 0.5 to 15 centimeters of low-grade ore on the hanging wall.

West of the main shaft (tiro principal) the main fissure is cut by a system of fractures and several premineral cross faults, which strike due north to $\mathrm{N} .15^{\circ} \mathrm{W}$. and dip $43^{\circ}$ to $85^{\circ} \mathrm{E}$. The ore is concentrated in the main vein below its intersections with faults and fractures, natural dams or traps having been formed where the west side of the principal fissure has moved relatively upward. The displacement on the largest of the cross faults ranges from half a meter to more than 3 meters. Postmineral movement has occurred on most of the faults. Ore unrelated to the cross faults is found in the gently dipping parts of the vein. The narrow parts contain very little antimony, but the wider parts of the vein, both in the gently dipping sections and below the intersecting faults and fractures, contain high-grade ore bodies.

The middle and western veins have been worked to a maximum depth of about 15 meters, but are filled to a depth of 10 meters. They are generally from 20 to 40 centimeters wide; the fissures are cut by several premineral faults, but the intersections of these faults and veins do not appear to have been adequately explored.

La Argentina mine has some of the best potentialities for undiscovered ore in the district. Although it was formerly the largest 
producer in the district, the mine has never been explored systematically, and it is now inactive except that the western vein is being worked on a small scale. If it were reopened, as it should be, ore would almost certainly be found at depth on the fault intersections and in the more flatly dipping parts of the veins. The water table is probably about 45 meters below the surface.

\section{LA IIIMEÑ̃ A}

The La Limeña mine (pl. 17) is in iron-stained gray siltstone, commonly without prominent bedding, belonging to the Triassic unit E. It contains but one vein, which strikes N. $20^{\circ}$ to $70^{\circ} \mathrm{W}$., dips $17^{\circ}$ to $78^{\circ} \mathrm{SW}$., and cuts across the bedding at low to moderate angles. This vein has a known length of 230 meters; its width varies from 10 centimeters to 1 meter and averages about 40 centimeters; and it has been mined to a vertical depth of 60.4 meters, or about 3.4 meters below the normal water table. It has been systematically developed from five main levels, at 15 meters, $24 \frac{1}{2}$ meters, 33 meters, 47 meters, and $56 \frac{1}{2}$ meters below the surface. The levels and sublevels contain about 1,000 meters of drifts and hundreds of meters of stopes, raises, and winzes. The mine has been one of the most productive in the district, and in 1943 was yiclding about 1 ton of high-grade ore and 3 tons of mill ore per day. The vein consists of banded coarse-grained quartz, antimony oxides, and inclusions of wall rock oriented parallel to the walls. The ore bodies are controlled entirely by changes in the strike and dip of the veins, being found in their more flatly dipping and more northerly striking parts. Nearly all of the ore northwest of the main shaft has been mined from above the second level. The influence of dip becomes evident on comparing the different levels. The average of the recorded dips is $41^{\circ}$ on the first level and $45^{\circ}$ on the second. On the third level, which was driven 30 meters westward from the shaft, the average dip is $55^{\circ}$, and on the fifth level that was driven only 15 meters westward from the shaft, the average dip is $70^{\circ}$. No ore was found west of the shaft below the third level, a fact that indicates the adverse influence of the downward steepening of the dip. The fifth level, however, should be extended at least 40 meters to the west, for the vein must flatten again below the secend level if the westerly strike of the vein on the fifth level persists to the west.

The workings east of the shaft are mostly inaccessible above the third level. None of the ore stoped from that level was more than 45 meters from the shaft, and more ore was found on the fourth and fifth levels than on the third As the average recorded dip on the third level is $68^{\circ}$, that on the third sublevel $66^{\circ}$, that on the fourth level $64^{\circ}$, and that on the fifth level $65^{\circ}$, it would seem that even small variations in dip may have a significant effect on ore deposition. 
The vein is cut by six small faults, found on the first to the third levels. The faults strike northeast to northwest and dip at moderate angles to the east and west. Three of them are definitely postmineral; the other three may be premineral. Their displacements are so small that no individual fault was identified on two adjacent levels. None is significant in controlling the ore.

The premineral movement on the vein structure prior to the mineralization was in part a relative upward movement of the hanging wall, indicated by the preferential mineralization of the flatly dipping sections of the vein, and in part a relative westward movement of the south side, indicated by the orientation of the gash veins in the footwall and by the preferential mineralization of the more northerly striking parts of the vein.

In the wall rock of the main ore bodies there has been conspicuous bleaching, which extends as much as 50 centimeters from the vein. Where no antimony is present, the wall rock is seldom bleached or otherwise altered for more than a few centimeters from the vein.

Except for an inconspicuous outcrop about 100 meters east of the main shaft, the vein was entirely concealed by gravel, which is 3 or 4 meters thick in some places. Most of the ore in the vein contains only 5 to 15 percent of antimony and is suitable only for mill feed. Some of the ore, however, can be hand-sorted to a shippinggrade product containing more than 40 percent of antimony. The total past production from the La Limeña mine is not known but is estimated to be between 2,000 to 5,000 tons of shipping ore.

The potentialities of the mine are very good, particularly for milling ore. Because of the possibility of discovering new veins in the hanging wall of the main vein, the crosscut from the shaft on the first level should be extended about 30 meters to the southeast. The main vein undoubtedly continues far below the present workings, and the average grade at depth should be similar to that near the surface. As at present, ore bodies are most likely to be found in the more flatly dipping parts of the vein. The $56 \frac{1}{2}$-meter level, the lowest in the mine, is just above the water table. Mining at greater depths will be complicated by the need of pumping.

\section{EL PALO VERDE}

The El Palo Verde mine (pl. 18), like the La Limeña, is in the siltstone of the Triassic unit $\mathrm{E}$. The main vein strikes $\mathrm{N} .70^{\circ}$ to $85^{\circ} \mathrm{W}$. and dips $50^{\circ}$ to $85^{\circ} \mathrm{SW}$. To the southeast, a subsidiary hanging-wall vein splits off, striking $\mathrm{N}$. $55^{\circ}$ to $75^{\circ} \mathrm{W}$. and dipping $70^{\circ}$ to $90^{\circ} \mathrm{S}$. The main vein is strong and persistent and contains 10 centimeters to 2 meters of coarse-grained quartz. It has been mined for a length of 170 meters and a depth of 55.6 meters, or 1.6 meters below the water 
table. The mine has about 820 meters of accessible drifts and crosscuts, and four main levels at depths of $23,35,50$, and $55 \frac{1}{2}$ meters. Both at the ends and at the bottom of the workings, the vein is strong and about 50 centimeters wide, which is the average width of the entire vein.

Most of the ore has come from above level 1, from about 6 meters above to 6 meters below level 2, and from the west end of level 4 . The recorded dips indicate their probable influence upon ore deposition. They average as follows: sublevel above level $1,67^{\circ}$; level 1 , $70^{\circ}$; level $2,61^{\circ}$; sublevel $2,72^{\circ}$; level $3,71^{\circ}$; and level $4,66^{\circ}$. The best ore is generally found in the flatter parts of the veins; most of it is in the hanging-wall quartz, although some is in the footwall quartz. No large bodies of high-grade ore have been found, but the mine contains large quantities of low-grade mill ore consisting of quartz with an intermixture of the antimony oxides. In June 1943 nearly all of the production was coming from the west end of the fourth level, where 10 to 20 centimeters of medium-grade and high-grade ore were found on the walls of the veins.

The vein is cut by a number of small faults, most of which strike N. $20^{\circ} \mathrm{W}$. to N. $20^{\circ} \mathrm{E}$. and dip steeply to the east. Most of the faults are postmineral, and the west sides have generally moved relatively southward. At the east end of the third level the miners found what they believe to be the east side of the main vein, offset to the south (pl. 18). What they found, however, is almost certainly a hangingwall vein; the main vein probably either ends at the fault or lies north of the present workings.

In some places the veins carry native gold and bromide or chloride of silver. The silver is always associated with the antimony oxides, while the gold is enclosed in the quartz.

Forty meters south of the El Palo Verde vein (pl. 15) lies what may be a continuation of the El Pensamiento vein. This vein has been explored to some extent near the surface. A crosscut on the third level was driven 40 meters southward from the main El Palo Verde vein, and it should be continued to the supposed El Pensamiento vein, which is probably only a few meters beyond the present face of the crosscut.

The total production from the El Palo Verde mine is probably between 1,000 and 2,000 tons of shipping ore. Since the veins probably persist many meters below the present workings, the mine is capable of yielding a large tonnage of low-grade mill ore. The 551/2meter level, which at present is the lowest, is $1 \frac{1}{2}$ meters below the water table, and can be worked only when the water is removed. The problem of water control will be more serious at greater depths, where pumps probably must be installed. 


\section{EL PENSAMIENTO}

The El Pensamiento mine (pl. 19) is in the same siltstone (Triassic unit E) as the La Limeña and El Palo Verde veins to the west. The vein is the widest and strongest in the district. It has been worked almost continuously for a length of 250 meters, and its probable continuations to the east and west indicate a length of about 500 meters. Its average width is about 60 centimeters. Within the 250 meters that has been worked, the mine contains about 360 meters of accessible drifts; it has been worked to a maximum depth of 36 meters. The two main levels are $11 \frac{1}{2}$ meters and 23 meters below the surface, and there is an intermediate level at 18 meters. The main shaft (tiro principal), which is inclined $50^{\circ}$ has a vertical depth of 30 meters. The mine has been relatively inactive since early 1942, though several gambusinos were working in the east end of the vein in 1943 .

The vein consists of coarse-grained milky quartz enclosing antimony oxide, which is generally concentrated near the hanging wall or the footwall. Much of the vein is barren, particularly where there is little variation in strike or dip. The average recorded dips on the three levels, from upper to lower, are $68^{\circ}, 74^{\circ}$, and $64^{\circ}$. The largest ore bodies in the mine are stituated as follows: (1) From the west end of the intermediate level up to the surface. The vein curves and flattens upward from $88^{\circ} \mathrm{N}$. on the intermediate level to $75^{\circ} \mathrm{S}$. at the surface. (2) Below the middle part of the lower level, below which the ore body is said to extend at least 14 meters down the dip. The dip flattens from $72^{\circ}$ on the level to $66^{\circ}$ in the lowest accessible part of the stope, 6 meters below the level. (3) At the east end of the lower level, where a large amount of ore has been mined. The dip changes from $53^{\circ}$ in the upper part of the stope to $43^{\circ}$ in its middle part and $55^{\circ}$ in its lowest accessible part. In this stope the maximum width of the vein is 1.8 meters. About 35 centimeters of ore was generally found on the hanging wall, and 10 to 20 centimeters in the middle part and in the footwall quartz. Much of the quartz is gold-bearing and probably contains a greater value in gold than in antimony.

The vein fissure is cut by a large number of small faults, most of which strike from due north to northeast and dip to the east. The west sides have moved relatively southward, with a maximum apparent displacement of 2 meters. All or nearly all of the faults are postmineral. Some postmineral faulting, also, has occurred within and parallel to the vein.

The past production is not known but is probably between 1,000 and 2,000 tons of shipping ore. Most of the ore in the vein is of such low grade as to be more suitable for milling than for shipping. The mine contains large quantities of low-grade ore and probably contains 
undiscovered deposits of high-grade ore. In addition, other veins probably exist in the footwall (see pl. 15) and possibly in the hanging wall. The water table is probably about 20 meters below the lowest workings.

\section{LA PIEDRA AZUL}

The La Piedra Azul mine (pl. 20) is in the siltstone and sandstone of the Triassic unit E. In this mine the veins strike N. $45^{\circ} \mathrm{E}$. to due east and dip $20^{\circ}$ to $50^{\circ} \mathrm{S}$. The fissures are crossed or terminated by premineral faults, occupied in places by vein material, that strike $\mathrm{N}$. $25^{\circ}$ to $35^{\circ} \mathrm{E}$. and dip $5^{\circ}$ to $55^{\circ} \mathrm{E}$. Two vein systems were probably formed, at least in part, at the same time. On the first level a vein striking N. $30^{\circ}$ E. appears to cross one that strikes nearly east, but to the northeast the former curves abruptly into a vein striking nearly east, and there neither vein displaces the other.

The La Piedra Azul veins consist largely of chalcedony with a higher percentage of antimony oxide and a much smaller proportion of coarse-grained quartz than any of the other veins in the district. Much of the ore is of high grade; the rest is a thorough intermixture of small grains of antimony oxide with chalcedony. In the highgrade ore small euhedral quartz crystals are disseminated throughout the antimony oxide, which also contains white porcelainlike chalcedony as irregular veinlets and in masses that seem to have replaced the ore minerals. High-grade bodies of straw-yellow to cream-colored antimony oxide are generally surrounded by low-grade intermixtures of chalcedony and olive-green antimony oxide.

The veins are cut by postmineral faults, which are parallel in strike to the premineral faults that strike N. $30^{\circ} \mathrm{E}$. but are generally steeper in dip; and in some places postmineral movement has occurred on the premineral faults. As indicated by slickensiding of the antimony oxides, the late faulting occurred after the oxidation of the antimony deposits. In one place euhedral calcite crystals were deposited along a postmineral fault cutting antimony oxide, and were disturbed and polished by a recurrence of faulting. The west sides of the late faults have moved relatively southward; the striations on their walls are nearly horizontal or plunge gently to the north.

The red and gray siltstone and purple sandstone adjacent to the principal ore bodies have been leached to white kaolinite and sand, the alteration commonly extending 60 or 70 centimeters from both walls of the vein. The veins generally cut across the bedding of the wall rocks, in places at large angles.

The mine has two levels, at 18 and 25 meters below the surface. The total length of the drifts and crosscuts is about 290 meters. The main shaft (tiro principal) is vertical and is 25.3 meters deep. 
The La Piedra Azul vein was discovered about 1936, but the first ore body was not found until late in 1941 or early in 1942. In 1943 the mine became the largest producer in the district, yielding 2 to 3 tons of high-grade ore and about 8 tons of low-grade milling ore per day. In the largest ore body, north of the main shaft, several hundred tons of ore had been mined by June 15, 1943, and an equal or larger amount remained to be mined. At that time the mine as a whole had probably produced at least 1,000 tons of high-grade ore. The outlook for the mine is excellent. Additional ore bodies could almost certainly be discovered in the known veins by extending development work laterally and downward. The crosscut on the first level should be extended 15 meters southward to intersect the hangingwall vein indicated in plate 15 . The water table is probably about 30 meters below the lowest workings.

\section{LA LOCA}

The La Loca mine (pl. 15) is owned by Roberto Perez of Caborca, Sonora, and is leased to Rafael Ruiz of El Antimonio. The mine is still in a very early stage of prospecting, and only a few tons of ore have been found. There are three shafts. From the main shaft, which is $20 \frac{1}{2}$ meters deep, a crosscut had been driven 5 meters to the south by June 14, 1943. The shaft penetrates 3 meters of gravel, then about 8 meters of the red siltstone of the Triassic unit $\mathrm{E}$. The lower workings are in altered white quartz porphyry, whose contact with the siltstone dips moderately to the south. No clearly defined vein or fracture system has been discovered, although small rounded bodies of ore have been found in the broken and altered porphyry. The ore, like that of the La Piedra Azul mine, consists of bunches of high-grade antimony oxide associated with an intermixture of chalcedony and antimony oxide.

The mine is so little developed that its potentialities are uncertain. It is possible that a well-defined vein may be discovered. The best ore will probably be found in the siltstone near the porphyry contact.

\section{LA MONTANA}

The La Montana mine (pl. 21) is on or near the contact of the Triassic units $\mathrm{E}$ and $\mathrm{F}$, in sandstone and siltstone. This mine, like the La Argentina mine, was formerly one of the largest producers in the district, but it has been inactive since May 1943. For several weeks prior to that time, about 8 tons per day of low-grade milling ore was produced from the stope fills. The total past production of the mine is probably between 2,000 and 4,000 tons of shipping ore. The deposit has not been systematically developed. The mine con- 
tains only 60 meters of regular workings, on a single level 22 meters: below the collar of the main shaft (tiro principal); the ore bodies, however, have been stoped by gambusinos for a length of 140 meters. Old workings are said to extend about 15 meters below the main level, but they are now filled with waste.

The principal vein strikes $\mathrm{N} .65^{\circ} \mathrm{E}$. to due east and dips $30^{\circ}$ to $57^{\circ} \mathrm{S}$. The vein fissure is cut by premineral fractures and faults of small displacement that have nearly the same strike as the main vein but dip $64^{\circ}$ to $90^{\circ} \mathrm{S}$. The ore bodies are localized at and below the intersections of the vein with the premineral fractures. The ore commonly extends downward from the intersections for several meters on these steep fractures, and for more than 10 meters on the flat vein.

Both the vein and the premineral fractures are cut nearly at right. angles by postmineral fractures and faults of small displacement that strike N. $5^{\circ}$ to $42^{\circ} \mathrm{W}$. and dip steeply to the east or west.

Most of the ore consists of cream, straw-yellow, and greenish-black antimony oxides in coarse-grained quartz, but some of it is a mixture of chalcedony and antimony oxide, resembling the typical ore of the La Piedra Azul mine. The ore is said to contain gold and silver.

The deep workings should be reopened and the flat vein explored at depth for intersections with other premineral faults. The chances of discovering new ore bodies are believed to be fairly good. The water table is probably about 15 to 20 meters below the lowest workings.

\section{LA BOFA}

The La Bofa mine (pl. 15), in arkosic sandstone of the Triassic unit $\mathrm{F}$, contains four veins, none of which has been worked for more than 12 meters below the surface. One strong vein strikes N. $65^{\circ} \mathrm{E}$. and dips $30^{\circ} \mathrm{SE}$., and the other strong vein strikes due north and dips $45^{\circ}$ to $70^{\circ} \mathrm{E}$. Much of the best ore, however, came from the intersection of two minor veins; one striking $\mathrm{N}$. $75^{\circ} \mathrm{E}$. and dipping $35^{\circ} \mathrm{N}$, the other striking N. $30^{\circ} \mathrm{W}$. and $65^{\circ} \mathrm{N}$. The intersection plunges about $25^{\circ} \mathrm{N}$., striking about N. $20^{\circ} \mathrm{W}$. Nearly all of the ore mined was close to the intersection. The maximum thickness of the ore was about $1 \frac{1}{2}$ meters and the maximum width about 3 meters.

The mine has probably produced several hundred tons of shipping ore and a somewhat larger amount of mill ore. The mine is not very promising.

\section{SAN FEDERICO}

The San Federico mine (pl. 15) is small, and though it was opened in the early days of the district it has been worked only now and again. In May and June 1943 it was inactive.

The main vein strikes N. $55^{\circ} \mathrm{W}$. to due west and dips $30^{\circ}$ to $55^{\circ} \mathrm{S}$. 
Its known length is 70 meters, and the deepest workings are 19 meters below the surface. The vein is crossed by four small faults, none of which appears to have been important in localizing the ore. The vein is generally 10 to 20 centimeters wide and consists of coarsegrained quartz enclosing a small proportion of antimony oxide. Where the vein has been mined out it probably was wider and of higher grade.

At its outcrop the vein is in fine-grained diorite, but the contact of this rock was the sandstone of the Triassic unit $\mathrm{F}$ meets the hanging wall about 4 meters down the dip from the outcrop; the strike of the contact is approximately parallel to that of the vein. The same contact meets the footwall about 3 meters farther down the dip, so that the vein occupies a thrust fault of small displacement. In the vicinity there are many other small veins in the diorite, but none has been worked to a depth of more than a few meters.

The total past production probably does not exceed 200 tons of shipping ore. The mine is not very promising.

\section{EL SALERO}

The El Salero mine (pl. 22) is in gray and red siltstone, interbedded with sandstone, in the upper part of the Triassic unit F. The main. vein, striking N. $20^{\circ}$ to $75^{\circ} \mathrm{E}$. and dipping $20^{\circ}$ to $60^{\circ} \mathrm{SE}$., is about 60 meters long, but it has been mined intensively only at its northeastern end, where it joins a vein striking N. $15^{\circ}$ to $25^{\circ} \mathrm{W}$. and dipping $25^{\circ}$ to $35^{\circ} \mathrm{E}$. The veins range in width from 10 centimeters to 2 meters, with an average of about 40 centimeters. The two fissures occupied by the veins are contemporaneous, and neither extends past their junction. Most of the ore has been found within 5 meters of this intersection, but some ore has been taken from three other veins in the mine, none of which has been explored for more than 40 meters along the strike. The mine has two levels, at 12 and 20 meters below the surface.

The ore, which is generally of low grade, consists of antimony oxide in quartz. Much of it has been thoroughly brecciated, and some of it ground to sand and powder, by postmineral and postoxidation faultingwithin and parallel to the veins. The appearance of the crushed ore is reflected in the name of the mine; "salero" means a storage place for salt.

Some of the ore contains abundant silver in the form of the silver bromide, bromyrite, which coats fractures in the antimony oxide.

In June 1943 the mine was yielding about 1 ton of mill ore per day. Its total past production is probably no more than 200 tons of shipping ore. Although the mine has been only slightly developed, its potentialities are believed to be good. 


\section{EL PROMONTORIO}

The El Promontorio mine contains two roughly parallel veins, each about 60 meters long, in the massive red siltstone of the Triassic unit E. The veins strike N. $40^{\circ}$ to $85^{\circ} \mathrm{E}$. and dip $2^{\circ}$ to $45^{\circ} \mathrm{S}$. The northern vein has been worked only near the surface, but the southern vein (pl. 23) has been mined out to a depth of about 12 meters, from two levels at depths of 11 and 17 meters. The lower level has been developed only near the east end of the mine, where the vein is narrow and contains little or no ore.

Only a little ore was found near the surface of the southern vein. The vein flattens, however, with depth, until it is almost horizontal at a depth of 10 meters; here it is 2.4 meters thick and contains a large amount of ore. Much of the ore is of low grade, but some high-grade ore is found in the footwall quartz. Southward the dip of the vein increases to $20^{\circ}$, but the old workings, which are said to extend 8 meters farther down the dip, are filled with waste. The best ore was found where the vein has a low dip and strikes about N. $70^{\circ} \mathrm{E}$., but the vein narrows and is barren near its eastern end, where the dip steepens and the strike swings to N. $30^{\circ}$ E. The ore controls are similar to those found in the La Limeña mine.

The color of the wall rock adjacent to the ore bodies has changed from red to white; the bleaching may extend as much as 30 centimeters from the vein.

The total past production is probably about 300 tons of shipping ore. If the veins were to be explored at greater depths, additional ore bodies would probably be found at places where the dips are flat.

\section{EL RINCóN}

The El Rincón mine (pl. 24), on the Cerro del Rincón, contains a large number of widely scattered small veins. The past production of this mine is negligible. The veins have an average length of about 20 meters and a width of 5 to 15 centimeters. They consist of coarsegrained quartz enclosing disseminated or irregularly distributed grains of antimony oxide. None of the veins has been worked to a depth of more than 5 meters down the dip. The eastern ones are in red conglomerate, siltstone, and sandstone of Triassic (?) unit $\mathrm{H}$ and Jurassic unit I, and lie parallel to and immediately below a contact with finegrained intrusive diorite. They strike due north to N. $20^{\circ} \mathrm{E}$. and $\operatorname{dip} 25^{\circ}$ to $30^{\circ} \mathrm{W}$. Other veins of similar strike but slightly steeper dip occupy fractures in the diorite. Another system of veins in the diorite strikes about $\mathrm{N} .60^{\circ} \mathrm{E}$. and dips steeply to the north. The veins in the diorite are believed to occupy primary fractures. The diorite, which is dark when fresh, is commonly bleached for a distance of several centimeters from the veins.

As the veins are short and narrow, the mine is not promising. 


\section{LA FORTUNA MINE}

The La Fortuna mine (pl. 24), owned by Rafael Ruiz of El Antimonio, is in quartz porphyry of Tertiary (?) age. It is probably the most productive mine in the igneous rocks of the district, having produced about 1,000 tons of shipping ore. The vein has been mined for a distance of 120 meters and to a depth of more than 20 meters. The accessible workings extend to a depth of 18 meters; there are deeper old workings that have been filled with waste.

The vein may have cropped out near its western end, but elsewhere it was originally concealed by gravels up to $3 \frac{112}{2}$ meters deep. It strikes on the average about N. $85^{\circ} \mathrm{E}$., dips $37^{\circ}$ to $85^{\circ} \mathrm{N}$, and is $1 / 4$ to 3 meters wide. Down the dip the vein repeatedly splits, sending offshoots into the hanging wall that are flat near the vein but steepen to the north. Most of the ore is found under the junctions of the main vein with the offshoots.

In a vertical shaft 12 meters north of the outcrop of the vein, diorite overlies the quartz porphyry; and another shaft, 40 meters north of the vein, is entirely in diorite. No ore was found in these shafts, but neither may have reached the vein. The La Fortuna vein may therefore be approximately parallel to a contact between porphyry and the overlying diorite.

The porphyry adjacent to the vein is chalky white in color and has been impregnated with calcite.

There may be undiscovered ore at depth, but it would be difficult to predict the chances of finding it. In the district as a whole, the veins in sedimentary rocks have proved better than those in igneous rocks. The depth of the water table is not known but may be 20 to 30 meters below the deepest workings.

\section{IA CARTA BLANCA}

The La Carta Blanca mine (pl. 24), owned by Rafael Ruiz of El Antimonio, is in the same large body of quartz porphyry that contains the La Fortuna vein. The La Carta Blanca vein has a known length of 190 meters and a possible length of 270 meters. It strikes $\mathrm{N} .20^{\circ}$ to $70^{\circ} \mathrm{E}$., curving gradually from an easterly strike near its south end to a northerly strike near its north end and dips $37^{\circ}$ to $80^{\circ}$ W. It has an average width of about 15 centimeters, and consists of quartz enclosing rather evenly distributed grains of antimony oxide. Most of the ore is of low grade, but some good ore was found in the more flatly dipping parts of the vein. The wall rock is commonly altered, though not so much as that along the Fortuna vein.

The vein is believed to occupy a primary fracture in the quartz porphyry, for it is parallel to one of three well-developed systems of fractures, nearly perpendicular to one another.

$840118-49-3$ 
The workings are shallow except in the central part of the vein, where the only tunnel in the district was driven to intersect the vein at a depth of 18 meters below the surface. A small amount of ore was found in the tunnel. The total past production is probably about 100 tons of shipping ore. The mine cannot be regarded as very promising, in view of the small width of the vein and the lack of marked variations in dip. If the La Carta Blanca vein continues northward and the Fortuna vein westward from the present workings, the two veins must intersect, with a junction plunging moderately to the northwest. If present, the junction could be discovered easily by trenching the shallow alluvium. The water table is probably at least 40 meters below the level of the tunnel.

\section{EL DIVISADERO}

The El Divisadero vein (pl. 24), owned by Rafael Ruz of El Antimonio, is parallel to the southern part of the La Carta Blanca vein and in the same intrusive body of quartz porphyry. It strikes N. $47^{\circ}$ to $60^{\circ} \mathrm{E}$. and dips $67^{\circ}$ to $75^{\circ} \mathrm{N}$. It has a known length of 35 meters and a possible length of 80 meters; its average width is less than 10 centimeters. It has been developed to a slight extent by three inclined shafts, each of which extend about 10 meters down the dip of the vein. Only a little ore, all of low grade, has been found; the past production is negligible, and the mine is not promising.

\section{LA ESCONDIDA}

The vein developed in the La Escondida mine (pl. 25) was once covered with 20 to 25 meters of the old high gravel (older alluvium), characteristic of much of the southern part of the district, but it was in part uncovered by recent erosion. Its history suggests that a number of other veins may lie undiscovered beneath the older alluvium which is abundant in this part of the district, or beneath the thinner more recent alluvium found farther north.

The vein is in brown sandstone, the bedding of which is at low to moderate angles. The relation of this sandstone to the sedimentary formations that crop out farther north is uncertain, because of the absence of outcrops in the intervening area. The known length of the vein is 70 meters and its average width 20 centimeters. It strikes N. $30^{\circ}$ to $50^{\circ} \mathrm{E}$. and dips $49^{\circ}$ to $62^{\circ} \mathrm{NW}$. The vein splits near its south end into two branches, each containing some antimony in coarse-grained quartz.

The workings are said to be about 7 meters deep; all but the upper 2 to 3 meters are filled with waste. In June 1943, a vertical shaft was being sunk 10 meters northwest of the outcrop to intersect the vein, which it will probably reach about 15 meters below the surface. Some ore may be found at depth. 


\section{PLACER DEPOSITS}

The El Antimonio district is the only one in North America that normally produces antimony ore from placers. No exact figures are obtainable, but according to local reports about 10 percent of the past and present production is of placer origin. The placers are mined by gambusinos, who sink shallow pits into the antimonybearing gravels.

Gravel deposits of three ages are found in the district. The youngest, which has not been mapped, is generally unconsolidated and is found in the present gullies. Most of the antimony ore in these youngest gravels was probably mined out in the early days.

Present production is chiefly derived from the younger of the two consolidated gravels (younger alluvium) which cover a large part of the central and northern part of the district (pls. 13 and 14). These gravels are commonly 1 to $3 \frac{1 / 2}{2}$ meters thick and mantle a bedrock surface that is more or less parallel to the present topographic surface. In general the underlying rocks are the same nonresistant Triassic sedimentary rocks that contain most of the antimony veins.

The older of the two cemented gravels (older alluvium) are found for the most part in the higher, southern half of the district (pls. 14 and 25), where they overlie a somewhat irregular bedrock surface. The larger masses of igneous rock and the more resistant sedimentary rocks protrude above these gravels. Recent streams have in some places cut through the old gravels and exposed the underlying bedrock; it was thus that the Escondida vein was uncovered. The older cemented gravels have been prospected for antimony in only a few places. As the antimony ore is concentrated near bedrock, and the thickness of the gravels, as much as 25 meters or more, has discouraged the sinking of prospect pits, all of the prospecting has been done on the walls of the stream channels that have been cut through the gravels to bedrock. The total production from these gravels has been very small, and none was recorded during May and June 1943.

Placer mining is most actively carried on in the area called $\mathrm{El}$ Placerito (pl. 15), northeast of the La Bolivia mine. Hundreds of pits have been sunk into the younger cemented gravels (younger alluvium) to the main antimony-bearing horizon, which lies $3 / 4$ to $2 \frac{1}{2}$ meters below the surface. Antimony is generally confined to a zone about half a meter thick. The ore occurs in the form of reddish, claystained, rounded and subrounded pebbles and boulders up to 20 centimeters in diameter, in partly cemented sand and gravel. The relatively barren overlying material is more thoroughly cemented, locally containing so much calcium carbonate as to form a caliche. Less thoroughly cemented gravel generally intervenes between the 
antimony horizon and the bedrock. Where old stream channels are found, they are commonly worked for their gold content, but only a negligible amount of gold is found at the antimony horizon.

According to the gambusinos a cubic meter of material from the ore-bearing layer in the average pit yields from 50 to 70 kilograms of antimony ore assaying about 45 percent in antimony. The total production from El Placerito is said to be over 1,000 metric tons of ore, and the aggregate production from the other placer deposits is probably at least as great.

Although the source of the ore in the northern part of El Placerito is uncertain, the antimony placers can generally be traced to the veins from which the ore was derived. Many of the productive veins completely or partly covered with gravel must have been discovered by the placer miners. Alluvial or stream-deposited placers grade upward in places into talus placers derived directly from the veins without the aid of stream action.

The region around the La Limeña, El Palo Verde, El Pensamiento, and La Piedra Azul mines presumably contains placer deposits, but if so they have not been worked, perhaps because of the thickness of the gravels, which ranges from 2 to 4 meters.

\section{RESERVES}

As is usual with antimony deposits, none of the reserves in the mines of the El Antimonio district can be regarded as "measured." No sampling has been done, because the average grade has been secondary in importance to the relative abundance of high-grade ore. Highgrade deposits are always mined out as soon as found, and ore is never blocked out and measured in advance of mining.

The district contains relatively large reserves of "indicated" ore, and for such ore also, specific measurements are lacking. This indicated ore is of three types: (1) High-grade ore still contained in the developed or partly developed veins and placer deposits. From 1,000 to 3,000 metric tons of ore containing 45 percent of antimony may reasonably be expected. Of this total one-fourth is in placer deposits, one-fourth in the La Piedra Azul veins, and the rest in other veins. (2) Low-grade mill ore in the developed parts of the veins. Probably 40,000 to 60,000 tons of ore containing 5 to 10 percent of antimony is to be expected. Much of this ore is in partly blocked out but unsampled parts of the La Limeña, El Palo Verde, and El Pensamiento veins. The rest consists largely of stope fills and unmined ground in the La Montana, La Argentina, El Salero, and La Piedra Azul mines. (3) Dump ore from all the mines. Of this there probably remains at least 5,000 to 10,000 tons containing 10 to 15 percent of antimony, 
but much of the dump ore has already been milled during the past year. Fortunately the miners of this district have in recent years been making separate dumps of the low-grade ore rejected in the process of sorting out the shipping ore. In all other antimony districts in Mexico, the rejected ore has been mixed with the waste, but in the El Antimonio district it is readily available for milling.

The following estimates of "inferred" reserves are based upon the assumption that the larger known veins continue to a depth of 150 meters vertically below their surface outcrops; that the ore bodies within this range are controlled by favorable structural conditions rather than by depth below the surface; and that some veins and placer deposits remain to be discovered. The reserves consist of three classes: (1) High-grade ore in veins. The quantity to a depth of 150 meters is probably at least half of the total past production and is estimated to be 25,000 to 50,000 tons of ore containing 45 percent of antimony. (2) High-grade ore in placers. Probably at least 1,000 tons and possibly as much as 3,000 tons of placer ore containing 45 percent of antimony is available. Production seems most likely to be increased by discovery of placers derived from the La Limeña-La Piedra Azul group of veins. (3) Low-grade mill ore. It is within reason to count on at least 50,000 and possibly as much as 150,000 tons of milling ore containing 5 to 10 percent of antimony. Such ore will be found in undiscovered veins and in unexplored parts of the known veins within 150 meters below the surface.

The different classes of reserves are summarized as follows:

Reserves of antimony

\begin{tabular}{|c|c|c|c|}
\hline & $\begin{array}{c}\text { Ore } \\
\text { (metric tons) }\end{array}$ & $\begin{array}{c}\text { Antimony } \\
\text { (percent) }\end{array}$ & $\underset{\text { (tons) }}{\text { Antimony }}$ \\
\hline \multirow[t]{2}{*}{$\begin{array}{l}\text { Indicated ore: } \\
\text { High-grade in veins and } \\
\text { placers } \\
\text { Mill ore in veins } \\
\text { Dump ore }\end{array}$} & $\begin{array}{r}1,000-\quad 3,000 \\
40,000-60,000 \\
5,000-10,000\end{array}$ & $\begin{array}{r}45 \\
5-10 \\
10-15\end{array}$ & $\begin{array}{r}450-1,350 \\
2,000-6,000 \\
500-1,500\end{array}$ \\
\hline & $46,000-73,000$ & $|-\ldots-n|$ & $2,950-8,850$ \\
\hline \multirow[t]{3}{*}{$\begin{array}{l}\text { Inferred ore: } \\
\text { High-grade in veins } \\
\text { High-grade in placers. } \\
\text { Mill ore in veins }\end{array}$} & $\begin{array}{r}25,000-50,000 \\
1,000-3,000 \\
50,000-150,000\end{array}$ & $\begin{array}{r}45 \\
45 \\
5-10\end{array}$ & $\begin{array}{r}11,250-22,500 \\
450-1,350 \\
2,500-15,000\end{array}$ \\
\hline & $76,000-203,000$ & $\ldots$ & $14,200-38,850$ \\
\hline & $122,000-276,000$ & $\ldots$ & $17,150-47,700$ \\
\hline
\end{tabular}




\section{FUTURE OF THE DISTRICT}

The El Antimonio district should be a large producer of antimony ore for at least 15 years in the future. Since much of the readily available high-grade ore has already been mined, the future will depend largely upon utilization of low-grade ore, development of known veins to greater depths, and discovery of new veins. Milling of low-grade ore, assaying from 10 to 15 percent of antimony, was begun about 1940 but because of the difficulties in milling antimony oxide ore the recovery is not more than 50 percent. Complete utilization of the low-grade ores will depend upon the development of more efficient and economical methods of recovering the antimony oxides.

The two deepest mines in the district, the La Limeña and the $\mathrm{El}$ Palo Verde, extend slightly below the water table, which is at a depth of less than 60 meters. In all the mines the depth of the workings has been limited by the difficulty of coping with water, not by finding a lower limit to ore deposition. Where the structure is favorable, ore is found in the deepest workings. All available evidence indicates that the deposits are not near-surface features dying out at shallow depth, but that wherever favorable structure occurs ore will be found at depths greater than any that have hitherto been reached. Individual ore bodies narrow downward, just as they narrow upward; in mined-out parts of the vein, one ore body has succeeded another in depth. If, as is probable, this condition persists downward, new ore bodies should be found in the strong veins at considerable depths. Some of the weak veins may die out downward, but there are probably other weak veins, and possibly a few strong ones, at depth, that do not crop out at the surface. The ore is probably localized to a depth of several hundred meters by structural conditions, largely independent of depth. The water table will probably be found, however, at an average depth of 40 or 50 meters from the surface. Deeper mining will therefore necessitate pumping, and it will also require increasing use of modern hoisting equipment.

Veins now covered with gravel are likely to be discovered in the future. Their discovery could be greatly hastened by systematic exploration and development, and possibly by geophysical prospecting. Since many of the known veins, such as the La Piedra Azul, El Pensamiento, El Palo Verde, La Limeña, San Francisco, and La Fortuna, were partly or entirely concealed by gravel deposits, other veins are almost certainly still concealed.

At an unknown depth below the water table, the ore will consist predominantly of stibnite. Milling methods must then be revised to deal with the change in composition of the ore. 


\section{RECOMMENDATIONS}

Procedures by which a relatively small amount of development may result in the quick finding of ore are as follows, in the order of apparent promise:

1. In La Piedra Azul mine (pl. 20), the main shaft should be sunk below the second level to intersect the high-grade veins dipping toward the shaft which are exposed on that level, and lower levels should be developed on the vein systems to a depth of at least $\mathbf{5 0}$ meters.

2. The crosscut to the south on the third level of the EI Palo Verde mine (pl. 18) should be continued to the El Pensamiento(?) vein, which may be only a few meters beyond the end of the crosscut.

3. Intensive search should be made for the source of the placer ore in the gravels of the El Placerito area (pl. 15). The gambusinos may have overlooked rich veins in the bedrock in the central and western parts of the placer ground.

4. The drift in the northeastern part of the upper level of the La Piedra Azul mine (pl. 20) should be continued in the hope of picking up the east-striking vein system again, and if a vein is found, it should be followed eastward.

5. The drifts on both levels of the same mine should be extended southwestward on the chance that the main vein does not die out but turns again to the west, flattens, and localizes undiscovered ore bodies.

6. In the same mine the crosseut on the first level (pl. 20) should be extended 15 meters southward to intersect the hanging-wall vein indicated on the surface in plate 15 .

7. In El Salero mine (pl. 22) the wide quartz vein found in the north crosscut on the upper level should be followed northeastward, in the hope of reaching its intersection with the northwest-striking vein found on the same level 10 meters east of the main shaft. The vein intersection found in the southeastern part of this level should be followed down the pitch.

8. On the lower level of the same mine, the drifts should be extended northeastward to search for intersections with the northwest-striking veins. The same drifts should also be explored southward for similar veins intersections.

9. In the La Limeña mine (pl. 17) the crosscut from the shaft on the first level should be continued 30 meters or more to the southeast on the assumption that additional veins exist in the hanging wall of the main vein.

10. In the same mine, the fifth level should be extended westward at least 40 meters on the possibility that the vein, though steeping on the second level, has flattened again below.

11. In El Palo Verde mine (see section, pl. 18) the hanging-wall vein should be explored between levels 2 and 3 , where it seems likely that an undiscovered flatly dipping portion of the vein may be found.

12. On the east end of the third level of the same mine, the main vein is probably north of the present workings, offset by a postmineral(?) fault. This possibility should be explored.

13. In El Pensamiento mine (pl. 19) crosscuts should be driven on the lower level, north and south from the shaft, to search for additional veins in the walls.

14. In El Promontorio mine (pl. 23) the main vein, found in the end of the southern crosscut on the lower level, should be followed westward, below the main workings.

15. In La Loca mine (pl. 15) the sedimentary rocks south of the quartz porphyry found in the lower workings of the main shaft should be explored. 
16. In El Brasil mine (pl. 15) the intersection of the main vein with the northeast vein should be prospected to a greater depth.

17. A search should be made for a possible intersection of the La Fortuna and La Carta Blanca veins (pl. 24) by trenching in the gravels on the continuations of the known parts of the veins.

Long-term projects undertaken in the hope of discovering new veins or major extensions of old veins generally involve a considerable amount of expensive development work, often calling for the application of expert mining technique. The following recommendations are offered with regard to such projects:

1. The main La Argentina vein (pls. 15 and 16) and possibly the adjacent veins should be cleaned out and explored systematically to a depth of at least 75 meters. Somewhere below the present workings these veins probably flatten again, localizing ore bodies as yet undiscovered. If it appeared desirable from an engineering point of view, all of the La Argentina and El Brasil veins could be developed together in a single large mine.

2. The La Limeña, La Piedra Azul, La Montana, and possibly the San Francisco and La Fortuna mines should be developed to greater depths. Because of the low average grade of the ore in the El Pensamiento and El Palo Verde veins, deeper exploration in these two mines ought perhaps to await the development of better milling methods for treating low-grade ores. These two veins are, however, the strongest in the district, and offer the best promise of having deep continuations and containing large reserves. Where mining extends below the water table, pumps will have to be installed. Possibly one pump in the deepest mine of the La Limeña-La Piedra Azul group would control all the water in that group. If the supply of water is found to be sufficient for milling purposes, the management should consider the advisability of moving the concentration mill from its present location (see fig. 5) to a location near the source of the ore, in order to avoid a truck haul of about 5 kilometers.

3. More extensive crosscutting, with a view to finding new veins, should be done in the La Limeña-La Piedra Azul group of mines. Surface exploration can find only those ore bodies that reach the surface. The La Piedra Azul is an excellent example of a mine that would not have been discovered if only surface methods had been used, for the surface outcrops were unimpressive and the ore bodies do not extend to the surface.

4. Systematic exploration for new veins at and near the surface should be carried out. This would probably involve the digging of many shallow pits to bedrock and careful prospecting of the gravels for placer ore, which might incidentally result in the discovery of valuable placer deposits. Tabulation and plotting of the results on maps would aid in locating veins. All the known veins either cropped out or were located in or near gullies that had cut part way through the gravel. But areas embracing many square kilometers are covered with gravel, commonly to depths of 1 to $\mathbf{4}$ meters and in places to a much greater depth, and any veins in these areas would not have been discovered by the methods used in the past. The most favorable areas are believed to be: N. $50^{\circ} \mathrm{E}$. to S. $50^{\circ} \mathrm{E}$. of La Piedra Azul mine, north of El Pensamiento mine, N. $30^{\circ} \mathrm{W}$. to due south of the La Limeña mine, and underlying and west of the placer deposits of El Placerito. The large area between the San Francisco group of mines and the La Montana group of mines is also favorable, but no specific locations within the area can be given because of the general lack of outcrops and of knowledge con- 


\section{ANTIMONY DEPOSITS OF EL ANTIMONIO DISTRICT, MEXICO 117}

cerning the bedrock geology. The area north and west of the San Federico mine and the adjacent diorite intrusion is also favorable.

Geophysical prospecting might possibly detect concentrations of high-grade ore, but such prospecting has never been tried in the search for antimony; resistivity methods in particular are suggested. In general, the most favorable areas are probably those in the Triassic siltstones and sandstones near the igneous intrusions.

5. Mechanical methods, such as the installation of underground tracks and ore cars, should probably replace hand methods, at least in working the larger deposits.

6. The workings, at least in the large mines, should be accurately surveyed by transit methods. In the future, when deeper levels are developed, the probable position of ore bodies between the levels can often be estimated with the aid of cross sections on which the veins are projected in order to determine where the veins flatten. Such methods would make it possible to space the levels at intervals of 15 to 20 meters. Spacing them at 5 to 12 meters, as is done at present, involves much needless expense. 


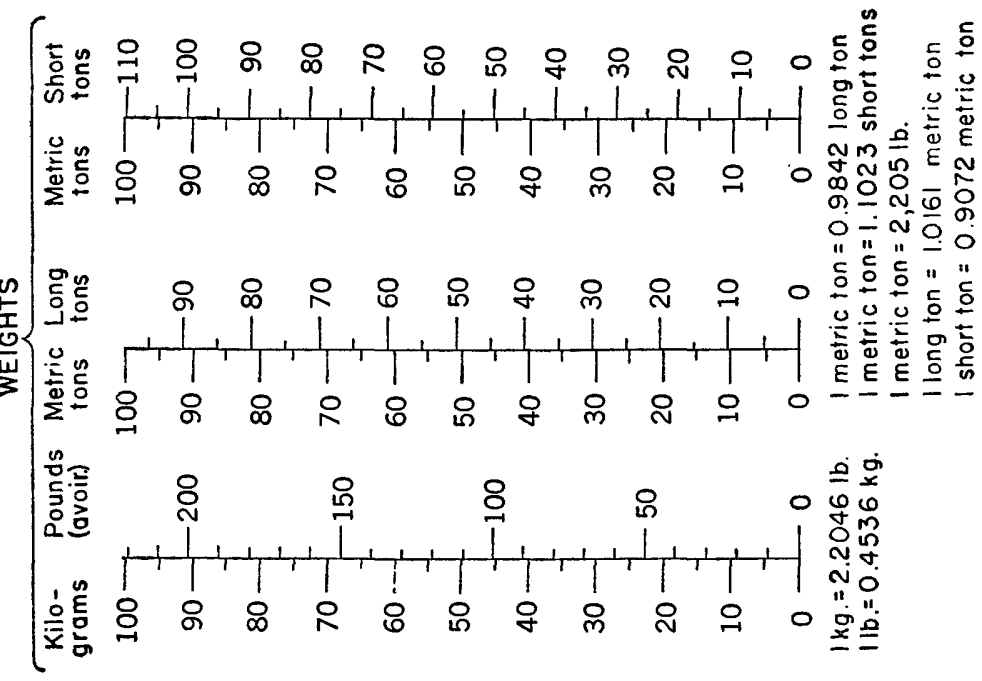

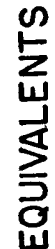

$\frac{O}{\Sigma}$

崖

(ك)

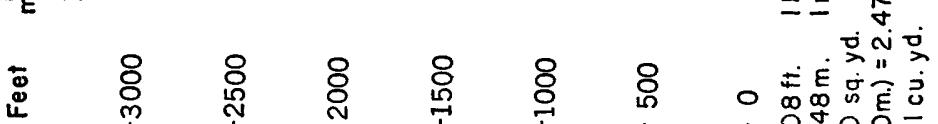

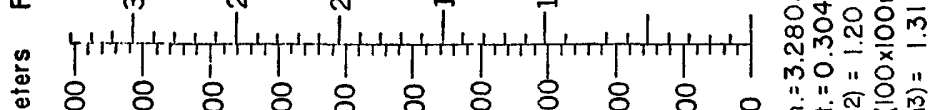

$\propto$

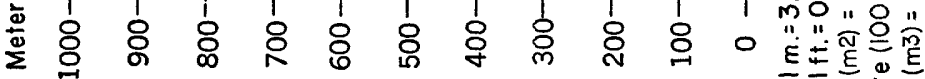
$\dot{E} \frac{0}{\circ} \dot{E}$ 宛导

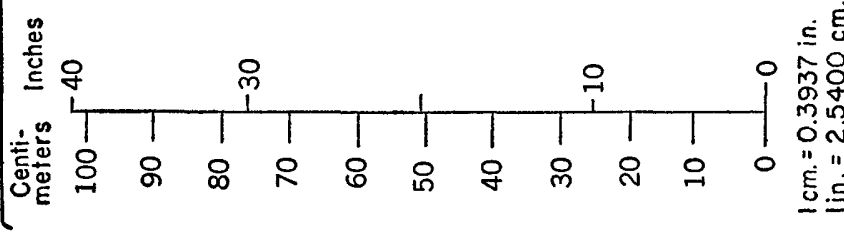

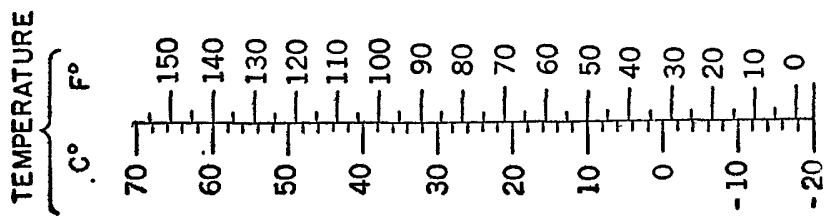




\section{INDEX}

\begin{abstract}
Acknowledgments.
Antimony ore, minerals associated with oxides. recommendations for future recovery of $115-$ reserves size of ore bodies

structural control of deposits sulfide.

Page

83

$-94$ $\pm 12-113$

94

$-95$
\end{abstract}

17

Cerro San Francisco area, geology of. pl. 13

Cerro San Francisco mine, description of

El Antimonio district, future of

El Brasil mine, description of. geology of recommendations for development........ 116

El Divisadero mine, description of geology of

El Palo Verde mine, description of . . . . ... 101-102 geology of . . .......... pls. 15, 18 recommendations for development...... 115, 116

El Pensamiento mine, description of geology of 103-104 reop. 15, 19

El Placerito deposit . ...................111-112, pl. 15 recommendations for development....... 115

E1 Promontorio mine, description of ........ 108 geology of . . . . . pls. 15, 23 recommendations for development....... 115

El Rincón mine. ................ 84, 108, pl. 24

El Salero mine, description.................. 107 geology of . ............. pl. 22 recommendations for development........ 115

Faults, description of ....... 90-91

Field work in the area ........................ 83

Fortuna area, geology of ............... pl. 24

Gold.

94

History of the area
Igneous rocks, age of Page

tynes of . .

La A rgentina mine, description of . ....... 99-100

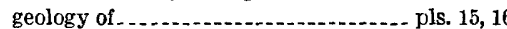

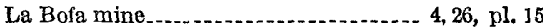

La Bolivia mine, description of ............. 98 geology of ....... pl. 15

La Carta Blanca mine, description of ...... $109-110$ geology of . .

La Escondida mine, description of .......... 110

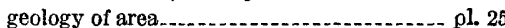

La Fortuna mine, description of ............ 109 geology of $\ldots$ pl. 24

La Limeña mine, description of .......... 100-101 geology of .................................. 15, 17 recommendations for development - 115, 116-117

La Montana mine, description of . .......... 105-106 geology of . . .

La Piedra Azul mine, description of ........ 104-105 geology of . . .......... pls. 15,20 recommendations for development...... 115, 116

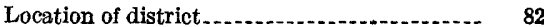

Montana area, geology of ................... pl. 15

Production of the district

Reserves of antimony, table................ 113

San Federico mine................ 84, 106-107, pl. 15

San Francisco area, geology of . . . ............ pl. 14

San Francisco mime................. 4, 15-16, pl. 14

San José mine . . ........................... 84, 96, pl. 14

San Miguel mine ....................... 84, 97-98

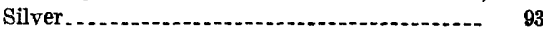

Stibnite. . . . .

Stratigraphy of the area.

Structure in the area. . . .

Veins, description of 
